\title{
THE PRINCIPLES OF LABOUR LAW OF THE EUROPEAN UNION AND UKRAINE: IN SEARCH OF HARMONIZATION
}

\author{
Rym O. M., Pylypenko P. D.
}

\section{INTRODUCTION}

Achievement of ambitious economic and social goals of the European Union is not possible without the EU's intervention into the regulation of internal labour markets of its Member States. Since the differences in the legal regulation of hired labour relations in the national labour legislation of the Member States cause impediments on the way to free movement of people and goods as well as distort economic competition.

It was initially envisaged that the internal market of the EU would be developing gradually under the effect of objective factors, viz. as the result of introduction of free trade without any restrictions. Elimination of economic as well as social and labor discrepancies between the Member States should be an inevitable consequence of the integration activity.

Along with that, the integration process has proven that intervention of the EU into the legal regulation of hired labour is still necessary, since time was passing, while approximation of the legal systems of the Member States was carried out in a slow and unstructured way. And the first issue that needed clarification was related to the fundamental provisions of legal regulation of hired labour, common for the EU Member States.

Introduction of the rules of cooperation between employees and employers took place with due account of the fundamental provisions for the construction and functioning of united Europe and was back then a component of the overall process of the EU law development.

Starting with the 1950ies the systems of law of the European countries have been developing under the effect of the integration processes taking place within the framework of the European communities, and then - within the EU established on their basis ${ }^{1}$. European integration caused outlining and affirmation of a certain set of fundamental principles accepted by all Member States and guiding the development of the common European system of law. Thus, the establishment of the European Union and the development of the system of the EU principles of law are interrelated and inseparable processes ${ }^{2}$.

\footnotetext{
${ }^{1}$ Стрєльцова О.В. Загальні принципи права як джерело права Європейського Союзу. Альманах права. 2012. Вип. 3. С. 265.

2 Юхимюк О. Еволюція системи загальних принципів права Європейського Союзу. Icmoрикоправовий часопис. 2016. № 1. C. 54. URL: http://nbuv.gov.ua/UJRN/ipch_2016_1_12.
} 
Having declared its intention to become a member of the European Union, Ukraine, though being late with performance of the commitment of harmonizing its legislation with the European standards, stills keeps declaring the ongoing process of adjustment of its system of law to the European provisions. At the same time, the state administration needs to realize that it is important not to just textually update Ukrainian legal regulation and attach the European form to it, but to approximate its legal framework to the European requirements concerning efficiency and effectiveness of its legal provisions in terms of content.

Due to this the countries having ambitious goals to acquire membership of the EU should analyze and study fundamental provisions of the law of the European Union, since only realization of the essence of the European integration processes and norms of law ensuring them will enable to quickly and fully harmonize the systems of law of the accession country and the EU. Respective scientific studies need to be done in the context of clarifying both general and special principles determining and mediating regulation of societal relations at the supranational level.

Legal regulation of labour relations is related to the European integration processes which keep affecting the labour law of Ukraine, which dates back to the distant "Soviet times", more and more. Over several decades, this domain of law has undergone complex evolution accompanied by intensive modernization and improvement of the forms and ways of labour force hiring. But even in spite of the fact that the key regulatory legal act regulating relations in the field of labour in Ukraine was approved back on December 10,1971 , the level of guarantees of labour rights of hired workers as of today is close to the international standards which in fact make up the basis for modern regulation of labour relations and are the key ideas (principles) of labour law. And it is this circumstance that gives grounds to consider that, unlike other fields of Ukrainian law, labour law is most adjusted in terms of its content and essence to the system of law of the European Union. It is such rules of labour relations regulation, caused by the social nature of the norms aimed to ensure an adequate level of guarantees of fundamental human rights in the field of employment, that have caused the need to bring the labour law of Ukraine as a prospective member of the European Union into conformity with the labour law of this organization and with common principles of legal regulation of hired labour.

The fact that Ukraine, unlike other states of the former post-Soviet space, has failed to complete codification of its labour legislation, seems to have played a positive role. Since when the Association Agreement between the European 
Union and its Member States, of the one part, and Ukraine, of the other part ${ }^{3}$ (hereinafter referred to as the Association Agreement) was signed in 2014, our state in fact gave its consent to the harmonization of its legislation with the requirements of the European Union, and the new Labour Code, the draft of which has been with the Parliament of Ukraine for already quite a time, must aim to implement the principles of labour law inherent in the European Union in its norms. Finally, there is a direct mention thereof in the Association Agreement, which stresses that the parties shall attach special importance to the affirmation of the rule of law, and cooperation must be taking place following the principle of respect for human rights and fundamental freedoms.

Clarification of the principles of the EU labour law, their content and functional direction constitute the key tasks of the present article.

\section{The notion of the principles of the European Union's law}

It is necessary to start with the characteristics of the principles of EU law in general, since they are also characteristic of the labour law as its structural element. That will contribute to the comprehensive understanding and development of an integral vision of the key principles of labour relations regulation in the European Union.

Lack of clear wording of the principles of EU law, though, as well as existence of such legal categories as "values", "fundamental freedoms", "fundamental rights", "general principles of law", "democratic principles", and "general provisions", that are related to them, make it more complicated to understand the key ideas of EU law in general and labour law in particular.

In the thesis research V.V. Kolesnichenko pays attention to inconsistent and confusing enshrinement of ideological provisions of EU law in the texts of the EU founding treaties ${ }^{4}$. In particular, the preamble to the current revision of the Treaty on European Union confirms dedication of the Member States to the principles of freedom, democracy, rule of law, respect for human rights and fundamental freedoms. It also declares dedication to the fundamental social rights determined by the European Social Charter (of 1961) and the Community Charter of the Fundamental Social Rights of Workers (of 1989). Besides that, the principle of sustainable development is mentioned there ${ }^{5}$.

\footnotetext{
${ }^{3}$ Угода про асоціацію між Україною, з однієї сторони, та Європейським Союзом, Європейським співтовариством 3 атомної енергії і їхніми державами-членами, з іншої сторони від 30.11.2015. URL: https://zakon3.rada.gov.ua/laws/show/984_011.

4 Колесніченко В.В. Принципи права Європейського Союзу: загальнотеоретичне дослідження : автореф. дис. на здобуття наук. ступеня канд. юрид. наук : спец. 12.00.01. «Теорія та історія держави і права; історія політичних і правових учень». Одеса, 2010. 22 с.

5 Консолідовані версії Договору про Свропейський Союз та Договору про функціонування Свропейського Союзу з протоколами та деклараціями. URL: http://zakon3.rada.gov.ua/laws/show/994_b06.
} 
Additionally, the basic principles of the European Union construction are fixed in Art. 2 of Title 1 "Common Provisions" of the Treaty on European Union. It states that the Union is based on the values of respect for human dignity, freedom, democracy, equality, rule of law and respect for human rights, in particular, concerning persons belonging to minorities. These values are common for all the Member States in the society where pluralism, nondiscrimination, tolerance, justice, solidarity and equality of women and men dominate. And before that similar wording was available in Art. 6 of the Treaty on European Union of 1992, where the respective basics of the Union construction were called "principles". Besides that, as systemic interpretation of the norms of the Treaty on European Union in the version of the Treaty of Lisbon shows, in other articles of the same document (for instance, Art. 21) the above values are called "principles".

Absence of consistency in the layout of EU law principles still does not refute the fact that they constitute the fundamental basis of the law of acquis communautaire. Moreover, the respective fundamental ideas are not the invention of the European Union. They reflect the principles of law that are directly determined by the achieved level of the development of mankind. That is, the so called fundamental ${ }^{7}$ (general human ${ }^{8}$, general law ${ }^{9}$, or civilization ${ }^{10}$ ) principles of law. Accumulating the best ideas, solutions and schemes of legal system construction, they, in the opinion of O.A. Radzivill, constitute the embodiment of the "spirit" of the Western legal tradition - a unique and rather successful experience of coordination of mainly individualistically substantiated principles of natural law with socially oriented norms of the public and state order. And it is them as the most tested by time achievements of the civilization in the field of legal regulation of societal relations that the subjects of both private and public private relations are mostly guided by ${ }^{11}$.

At the same time, as M. Cohen and B. Schramm rightfully point out, general legal principles constitute the main rules the content of which is very general

\footnotetext{
${ }^{6}$ Колесніченко В.В. Принципи права Європейського Союзу у світлі Лісабонського договору. Актуальні проблеми політики : зб. наук. пр. / редкол.: С.В. Ківалов (керівник авт. кол.), Л.І. Кормич (ред.), М.А. Польовий (відп. секр.) та ін.; ОНЮА, Південноукр. центр гендер. проблем. Одеса, 2009. Вип. 36. С. 183.

7 Погребняк С.П. Основоположні принципи права (змістовна характеристика). Харків : Право, 2008. $240 \mathrm{c}$.

${ }^{8}$ Фулей Т. Загальнолюдські (загальноцивілізаційні) принципи права: деякі теоретичні аспекти. Право України. 2003. № 7. С. 24-29.

${ }^{9}$ Колодій А.М. Принципи права: генеза, поняття, класифікація та реалізація. Альманах права. 2012. Вип. 3. С. $42-46$.

10 Загальна теорія держави і права : підручник для студентів юридичних вищих навчальних закладів / М.В. Цвік, О.В. Петришин, Л.В. Авраменко та ін. ; за ред. М.В. Цвіка, О.В. Петришина. Харків : Право, 2009. C. 199.

${ }^{11}$ Радзівілл О.А. Загальноправові принципи як джерела міжнародного економічного права. Юридична наука. 2014. № 2. C. 54-55. URL: http://nbuv.gov.ua/UJRN/jnn_2014_2_7.
} 
and abstract ${ }^{12}$. It is this peculiarity of theirs that helps use fundamental principles of law in case it is necessary to fill out actual or prospective gaps in legal regulation, meaningfully determine the system of law and its structural elements. Since they are characteristic of the law in general and are present in all legal norms and institutes, the law of the European Union is also definitely permeated with respective ideas.

Besides that, the legal system of the EU is developed and functions in accordance with the unified and mutually interdependent comprehensive system of the principles of law of the European Union, the content of which was enriched as the result of approval of the Treaty of Lisbon ${ }^{13}$.

Having researched a great scope of modern scientific literature on the system and types of principles of EU law, V.V. Kolesnichenko sums it up that, in spite of plenty of options for classifying the principles of EU law, still today there isn't any generally acknowledged classification that would combine all the principles of EU law into a system ${ }^{14}$. And variety of the principles of EU law is accounted for by the scholar by the differences in their functional direction. Thus, some of them determine the correlation of the EU system of law with national legal systems of states included into the Union, others - its correlation with the rest of the world, the third ones - the basics of the EU order and functioning, the fourth - the key principles within the framework of specific fields of legal regulation of the EU, etc ${ }^{15}$.

T.A. Postovalova is of the same opinion, and she separates functional, general and sectoral principles of EU law. And in labour law only the principle of equal payment for men and women for the same labour is sectoral, to her belief. While functional principles, as a component of the legal legacy of the EU, determine the rules of international of the supranational law with the systems of law of the Member States. At the same time, the scholar stresses that classification boundaries between the above groups are not stable. Rather vice versa, they are changeable. For example, the principle of legitimacy in the field of justice can be enshrined as procedural guarantees of the fundamental rights and freedoms of an individual ${ }^{16}$.

\footnotetext{
${ }^{12}$ Marcelo Kohen \& Berenice Schramm. General Principles of Law. Oxford Bibliographies Online, Ed. Tony Carty. New York : Oxford University Press, 2013. P. 1.

13 Колесніченко В.В. Принципи права Європейського Союзу у світлі Лісабонського договору. Актуальні проблеми політики : зб. наук. пр. / редкол.: С.В. Ківалов (керівник авт. кол.), Л.І. Кормич (ред.), М.А. Польовий (відп. секр.) та ін. ; ОНЮА, Південноукр. центр гендер. проблем. Одеса, 2009. Вип. 36. С. 187.

14 Колесніченко В.В. Принципи права Європейського Союзу: загальнотеоретичне дослідження : автореф. дис. на здобуття наук. ступеня канд. юрид. наук : спец. 12.00.01. «Теорія та історія держави і права; історія політичних і правових учень». Одеса, 2010. С. 13.

${ }^{15}$ Ibid. C. 9.

16 Постовалова Т.А. Трудовое право Европейского Союза: теория и практика. «Издательство «Проспект», 2015. 544 с.
} 
The above makes its more complicated to analyze the principles of EU law as well as to clarify the place and the peculiarities of the fundamental ideas determining legal regulation of the hired labour relations, within the system of fundamental principles of EU law. Still a way out can be found in such a situation, which seems, on the one hand, to be a dead-end. With this in view the concept of the general principles of law of the European Union can be used, and it is possible to try and analyze the fundamental principles of EU law on their basis, as it is wide-spread among European scholars-lawyers.

\section{The general principles of EU law and their implementation in the field of employment}

The notion "general principles of law" has been known since the period of establishment of three European integration unions. However, in the founding treaties under which the European communities were founded, only the general principles of law were mentioned ${ }^{17}$. These legal acts did not disclose the notion and content of the latter. The problem of meaningful load of this notion has found its solution through the activities of the Court of Justice of the EU, which for the sake of liquidating legal gaps in primary law of the EU, has started developing the general principles of law of the Communities and has determined the latter as the fundamentals embodying the basic values of the EU system of law.

Developing the concept, which was to play an important role in the development of EU law and order, the Court of Justice of the EU resorted to most expanding and teleological interpretation of the provisions of agreements on the general principles of law $^{18}$. In the course of the law-enforcement activity it developed a number of fundamental legal principles of an unwritten nature and determined them as the highest norms in the EU system of law, that constitute one of the key criteria of legitimacy of any forms of activity related to the functioning of the European integration unions ${ }^{19}$. As J.-L. Bergel rightfully indicates, the general principles of law should not necessarily be manifested in the texts of the legislation, but should necessarily be applied in the judicial practice $^{20}$.

The Court took the general principles that were the same for legal orders of the Member States, the legal principles of the functioning of institutions and

\footnotetext{
17 Энтин М.Л. Суд европейских сообществ: правовые формы обеспечения западноевропейской интеграции. М осква : Международные отношения, 1987. С. 59.

${ }^{18}$ Стрєльцова О.В. Загальні принципи права як джерело права Європейського Союзу. Альманах права. 2012. Вип. 3. С. 266 URL: http://dspace.nbuv.gov.ua/bitstream/handle/123456789/63930/55-Streltsov.pdf ?sequence $=1$.

19 Энтин М.Л. Суд европейских сообществ: правовые формы обеспечения западноевропейской интеграции. Москва : Международные отношения, 1987. С. 60.

${ }^{20}$ Бержель Ж.-Л. Общая теория права. Москва, 2000. С. 168.
} 
other bodies of the EU as well as the principles and customs of international law as the basis for the construction of the general principles of EU law ${ }^{21}$. Later, the principle approved by the Court of Justice of the EU, regardless of the sources of its origin, became a self-sufficient norm of EU law, was separated from the similar norm in the legal system or systems from which it was borrowed, and acquired the status of the general principle of EU law, if it corresponded to the interests of the European integration ${ }^{22}$. Viz, it filled in the gaps in EU law and helped interpret the legal acts of the Community and the Member States ${ }^{23}$.

Thus, the judicial practice has affirmed the concept of the general principles of EU law, has promoted partial enshrinement of those principles in the founding treaties of the Union as well as has caused a wide scientific discussion which is still going on. In particular, till present both foreign and Ukrainian researchers of EU law keep arguing about the development of a specific list and content of general principles. W. Kearns, for example, classifies the general principles by the source of primary expression of a certain fundamental idea taken as the basis of their development ${ }^{24}$. While L. Entin refers to the general principles of EU law only fundamental rights guaranteed by the European Convention for the Protection of Human Rights and Fundamental Freedoms and stemming from the constitutional traditions common for the Member States ${ }^{25}$.

A. Tatham also writes about belonging of the fundamental human rights to the general principles of EU law. Besides that, in his opinion, the principles of legal certainty, proportionality, equal treatment or non-discrimination as well as the principles of direct effect, rule and effectiveness of EU law are also general ${ }^{26}$. The authors of the learning guide European Union Law also take a similar stand. In particular, they write about the principles of respect for fundamental human rights, proportionality, equality or non-discrimination, legal certainty, observance of due-process rights and subsidiarity ${ }^{27}$. Ukrainian scholars V. Opryshko, A. Omelchenko, and A. Fastovets are of the same of opinion ${ }^{28}$.

\footnotetext{
${ }^{21}$ Право Свропейського Союзу : навчальний посібник / За ред. Р.А. Петрова. 5-те видання, змінене і доповнене. Київ : Істина, 2013. С. 41.

22 Назаренко О.А. Загальні принципи права ЄС в правовій системі ЄС. Правове регулювання економіки. 2015. № 15. C. 244. URL: http://irbis-nbuv.gov.ua/cgi-bin/irbis_nbuv/cgiirbis_64.exe?C21 $\mathrm{COM}=2 \& I 21 \mathrm{DBN}=\mathrm{UJRN} \& \mathrm{P} 21 \mathrm{DBN}=\mathrm{UJRN} \& I M A G E$ FILE_DOWNLOAD=1\&Image_file_name=PDF/pre_2 015_15_23.pdf.

${ }^{23}$ Lenaerts K., J.A. Gutierrez-Fons. The constitutional allocation of powers and general principles of EU Law. Common Market Law Review 47. 2010, P. 1629.

${ }^{24}$ Кернз В. Вступ до права Європейського Союзу / пер. з англ. Київ : Знання, 2003. С. 104.

25 ПРАВО Европейского Союза. НОВЫЙ ЭТАП ЭВОЛЮЦИИ: 2009-2017 годы. Москва : Изд-во «Аксиом», 2009. С. 89-91. URL: http://www.eurocollege.ru/fileserver/books/esi-library5.pdf.

${ }^{26}$ Татам А. Право Європейського Союзу / пер. $з$ англ. Київ : Абрис, 1998. С. 70.

${ }^{27}$ Право Свропейського Союзу : навчальний посібник / за ред. Р.А. Петрова. 5-те видання, змінене і доповнене. Київ : Істина, 2013. С. 41.

${ }^{28}$ Опришко В.Ф. Право Європейського Союзу. Загальна частина : підручник / В.Ф. Опришко, А.В. Омельченко, А.С. Фастовець. Київ : КНЕУ, 2002. С. 138.
} 
Of interest is the approach presented by J. Hanlon who suggests an open list of the general principles of EU law. In his opinion, these are the rule of law, protection of the rights and freedoms of an individual, subsidiarity and proportionality, non-discrimination, protection against unfair competition, and others $^{29}$.

Still, detailed analysis of numerous authors' classifications of the general principles of EU law has enabled to identify a part of principles belonging of which to the general principles of law is acknowledged by most scholars. These, in particular, include the principle of legal certainty, proportionality, subsidiarity, rule of law and direct effect, fundamental rights, equality.

\section{The principle of legal certainty}

The principle of legal certainty means that application of law in a specific situation must be predictable ${ }^{30}$. It is divided into two specific subprinciples: impossibility of reverse effect and protection of legitimate expectations. Impossibility of reverse effect presupposes that, with the lack of clear evidence about the opposite, the legislation cannot have any reverse effect and be valid for the relations that arose prior to enactment of the respective legal act. This rule, in particular, does not allow the secondary legislation of the EU to come into effect prior to its publication. In fact, according to the substantive law of the $\mathrm{EU}$, reverse effect is allowed only in cases when legislative goals cannot be achieved in any other way, on condition the principle of protection of legitimate expectations is followed ${ }^{31}$. And protection of legitimate expectations presuppose the right of an individual to act in a reasonable and careful way within the law as well as to expect that current legislation will keep being applied.

\section{Proportionality and subsidiarity}

The fundamental principles of EU law also include proportionality and subsidiarity. These principles derive from a wider principle of competence conferral (Article 5 of the Treaty on European Union), which means that the Union shall act within the limits of the competences conferred upon it by the Member States under the founding treaties for the sake of attaining the objectives set out therein. The competences not conferred upon the Union in the founding treaties remain with the Member States.

\footnotetext{
${ }^{29}$ Hanlon J. European Community Law. London. 2003. Pp. 65-73.

${ }^{30}$ Стрєльцова О.В. Загальні принципи права як джерело права Європейського Союзу. Альманах права. 2012. Вип. 3. С. 267. URL: http://dspace.nbuv.gov.ua/bitstream/handle/123456789/63930/55-Streltsov.pdf? sequence $=1$.

31 Право Європейського Союзу : навчальний посібник /За ред. Р.А. Петрова. 5-те видання, змінене і доповнене. Київ : Істина, 2013. С. 42-43.
} 
The principle of proportionality, as one of the key general principles of law of the EU, presupposes a clear relation between the means and objectives of the EU legislation, and the benefits for the society must be higher than the inconveniences caused. For example, the principle of proportionality is applied for determining the legitimacy of national restrictions for free movement of goods and movement of workers under Art. 36 and Art. 45 of the Treaty on the functioning of the European Union $^{32}$. That is, proportionality stands for achievement of balance between the objective and the activities aimed at its attainment.

Assessment of the compliance with the proportionality principle is made in three stages. First, it is clarified whether a specific activity carried out by the European Union or its Member States, corresponds to the attainment of the legitimate objective. After that it is assessed whether there is a need for specific activities aimed at attainment of the objective, as well as an opportunity for applying less restrictive means. And, finally, it is determined whether the influence on the interests of the stakeholders was not excessive.

According to the principle of subsidiarity in the fields that are not within its exclusive competence, the Union acts only in case and to the extent to which the Member States cannot adequately attain the objectives of the suggested activity at the central, regional, or local levels, while instead this would better be implemented at the level of the Union due to the scale or the results of the suggested activities. Practical application of this principle is made more complicated due to unclear differentiation of the competences of the Union and its Member States. Since the field of social policy is not within exclusive competence of the Community, it is possible to apply the principle of subsidiarity in $\mathrm{it}^{33}$.

Under the Protocol to the Treaty of Lisbon of 2007 about application of the principles of proportionality and subsidiarity, each European institution shall respect the principles of proportionality and subsidiarity the way they are determined in Art. 5 of the Treaty on European Union. The protocol sets a clear legislative procedure for the adoption of the regulatory legal acts of the Community and examination of their correspondence to the principles of subsidiarity and proportionality.

\section{The rule of law and direct effect}

The next principle of the rule of law, standing out among the general principles, means that national systems of law of the EU countries should

\footnotetext{
32 Право Свропейського Союзу : навчальний посібник / За ред. Р.А. Петрова. 5-те видання, змінене і доповнене. Київ: Істина, 2013. С. 42; Judgment of 23 November 1989, Torfaen Borough Council v B \& Q plc., Case C-145/88, ECLI:EU:C:1989:593.

33 Европейское право : учебник для вузов / под общ. ред. д. ю. н., проф. Л.М. Энтина. Москва : HOPMA, 2000. C. 557.
} 
correspond and be subordinated to the legal procedure of the Union. However, as many other general principles of law, it has not found its legal enshrinement in legal acts. Therefore, the answer to the question what should be done in case there is a need to clarify the correlation of the European Union law and supranational law has been provided by the Court of Justice of the EU. Though more than half a century has passed since the recognition of the rule-of-law principle in the $\mathrm{EU}^{34}$, the rules of interaction of acquis communautaire and national law are considerably non-codified and derive from the judicial practice ${ }^{35}$.

Quite a number of cases that have been subject to the consideration by the Court of Justice of the EU has led to the development of a certain system of interrelated and stable provisions in the precedent practice of a certain system, that in their integrity determine the general principle of the rule of law in the $\mathrm{EU}^{36}$. In general, its content can be narrowed down to the following provisions. Namely, the rule of law in the EU presupposes priority of the norms of supranational law over the national one, that is law of the European Union over the law of the Member States. Also, the norms of national law cannot and shall not run counter to the norms of supranational law ${ }^{37}$.

One of the cornerstones of the rule-of-law principle, in the opinion of O. Holovko-Havrysheva, is direct effect of EU law ${ }^{38}$. Still, other authors convince of the independence of that principle ${ }^{39}$. But still, in spite of minor divergences, their understanding of its meaning is the same for everyone. Namely, the principle of direct effect stands for the binding nature of the norms of EU law for all the Member States. It also provides an opportunity for individuals to use the provisions of the EU legal acts in courts for the sake of protecting their interests. In the practice of the Court of Justice of the EU direct effect of the norms of founding treaties and the norms available in the secondary law of the EU is recognized ${ }^{40}$. Direct effect and direct application are primarily

\footnotetext{
34 Judgment of 15 July 1964, Flaminio Costa v E.N.E.L., Case 6-64, ECLI:EU:C:1964:66.

35 Лазовскі А. Верховенство права Свропейського Союзу: юридична авантюра, що окупилась. Право Украйни. 2019. № 6. С. 35.

${ }^{36}$ Іванець А. Верховенство права Свропейського Союзу відносно національного права держав-членів : модель реформ для України «Гілея: науковий вісник»: Збірник наукових праць. Київ, 2012. Випуск 58 (додатки)

${ }^{37}$ Ibid.

${ }^{38}$ Головко-Гавришева О. Принцип верховенства права Європейського Союзу як основа взаємодії правової системи СС і національних правових систем держав членів. Вісник Львівського нащіонального університету. Серія Міжнародні відносини. 2017. Випуск 42. С. 228.

39 Брацук I.3. Теоретико-правові засади імплементації права Європейського Союзу в національне право держав-членів : монографія / за наук. ред. проф. М.М. Микієвича. Львів : ЛНУ імені Івана Франка, 2016. С. 37 ; Право Свропейського Союзу : навчальний посібник / За ред. Р.А. Петрова. 5-те видання, змінене і доповнене. Київ : Істина, 2013. С. 45.

40 Хартия ЕС об основных правах / под ред. д. ю. н., проф. С.Ю. Кашкина. Москва : Юриспруденция, 2001. C. 68.
} 
inherent in the norms of EU law, which definitely and indisputably set the commitment to act in a certain way; do not set any additional conditions or means for their implementation; as well as create legal consequences both for the Member States and for the subjects of national law ${ }^{41}$.

Thus, due to the rule of law and direct effect of EU law effectiveness of acquis communautaire is achieved ${ }^{42}$. In this respect Ye.N. Yehorova even points out an independent principle of EU law effectiveness, which, to her belief, was developed by the Court of Justice of the EU in a number of cases ${ }^{43}$. The essence of the principle lies in the provision of practical effect to the norms of EU law and best attainment of the objectives and tasks set in the Treaty on European Union ${ }^{44}$.

The rule of law and direct effect of EU law are often clarified along with the principles of integration and jurisdictional protection of EU law. Thus, O.M. Darmoris ${ }^{45}$ and L.M. Entin ${ }^{46}$ account for the integration of EU law by its automatic implementation in the systems of law of the Member States. That is, implementation of EU law norms does not require any national-level activities. The researchers claim that the principle was confirmed in the case Andrea Francovich and Danila Bonifaci and others $v$ Italian Republic ${ }^{47}$, which tells about the establishment of own system of law of the EU, that was integrated into the systems of law of the Member States and is hence obligatory for their judicial bodies, and the subjects of which are not just the Member States but private individuals within their jurisdiction as well. Moreover, the integration and jurisdictional protection mean that in all cases when there appears the need to apply EU law in order to resolve conflicts or disputes, national institutions and judicial authorities shall practice this ${ }^{48}$.

\footnotetext{
41 Головко-Гавришева О. Принцип верховенства права Європейського Союзу як основа взаємодії правової системи СС і національних правових систем держав-членів. Вісник Львівського національного університету. Серія Міжнародні відносини. 2017. Випуск 42. С. 228.

42 Лазовскі А. Верховенство права Свропейського Союзу: юридична авантюра, що окупилась. Право Украӥни. 2019. № 6. С. 35.

${ }^{43}$ Judgment of 5 March 1996, Brasserie du Pêcheur SA v Bundesrepublik Deutschland and The Queen v Secretary of State for Transport, ex parte: Factortame Ltd and others, Joined cases C-46/93 and C-48/93, ECLI:EU:C:1996:79; Judgment of 5 October 1994, Commission of the European Communities v. French Republic, Case C-381/93, ECLI:EU:C:1994:370.

${ }^{46}$ Егорова К.Н. Основы трудового права Европейского Союза : дисс. канд. юр. наук: спец. 12.00.10 «Международное право; Европейское право». Москва, 2013. С. 31.

45 Дарморіс О.М. Становлення та розвиток трудового права Європейського Союзу : дис. ... канд. юрид. наук : спеціальність 12.00.05 «Трудове право; право соціального забезпечення». Одеса, 2010. C. $43-65$.

46 ПРАВО Европейского Союза. НОВЫЙ ЭТАП ЭВОЛЮЦИИ: 2009-2017 годы. Москва : Изд-во «Аксиом», 2009. С. 69.

47 Judgment of 19 November 1991, Andrea Francovich and Danila Bonifaci and others V Italian Republic, Joined cases C-6/90 and C-9/90, ECLI:EU:C:1991:428.

${ }^{48}$ ПРАВО Европейского Союза. НОВЫЙ ЭТАП ЭВОЛЮЦИИ: 2009-2017 годы. Москва : Изд-во «Аксиом», 2009. С. 69.
} 
The suggested variant of interpretation of the integration and jurisdictional protection of EU law proves its direct link to the direct effect of EU law. Though EU law does not clearly set these principles, the legal doctrine still differentiates between them and considers them to be the ones supplementing the principle of direct effect of EU law ${ }^{49}$.

\section{Fundamental rights as the general principle of law}

The following general principle of EU law is closely connected to the concept of human rights, that is actively developing in Europe. In particular, in spite of the declaration of respect for human dignity, freedom, democracy, equality, rule of law and respect for human rights as the highest values of the EU, in the course of development of European Union law it was becoming more and more obvious that the EU citizens may suffer as the result of illegal regulatory acts of the EU.

It should be mentioned here that the European Economic Community was limited to economic issues and was remotely related to the protection of human rights. However, the times when the EU was considered a purely economic organization are in the past ${ }^{50}$. Activities of the Court of Justice of the European Union have contributed to such developments. It is this European institution that has for the first time protected fundamental human rights in the context of economic and commercial interests, ownership right, freedom of commerce and employment. The Court of Justice of the EU, though, was initially very much cautious about affirmation of the concept of human rights in EU law, since that could pose a threat for the Community's principle of the rule of law ${ }^{51}$.

In the course of expansion of the Community's mandate far beyond economic issues the situation changed. And gradually the Court of Justice of the EU recognized the need to protect fundamental rights at the level of the European Union. And addition, adding of the fundamental rights to the legal order of the EU was substantiated, no matter how strange it is, by the need to protect the principle of the rule of law in the EU. That was caused by the activities of national courts that resisted to the Union's actions since they considered the supremacy of the EU law to be a violation of fundamental rights protected by national constitutions ${ }^{52}$.

It all started in the 60ies of the 20th c. back then the founding treaties of the European Union did not set the list of fundamental rights, hence, in the context

\footnotetext{
${ }^{49}$ Право Європейського Союзу : навчальний посібник / За ред. Р.А. Петрова. 5-те видання, змінене і доповнене. Київ : Істина, 2013. С. 52.

50 Толкачова Н.Б. Принцип захисту основних прав людини у практиці Суду Європейських Співтовариств. Держава і право. 2009. Вип. 46. С. 532. URL: http://dspace.nbuv.gov.ua/ bitstream/handle/ 123456789/9075/93-Tolkachova.pdf? sequence $=1$.

${ }^{51}$ Комарова Т.В. Юрисдикція Суду Європейського Союзу. Харків : Право, 2010. С. 242.

${ }^{52}$ Витвицкая О., Горниг Г. Право Европейского Союза. Санкт-Петербург : Питер, 2005. С. 92.
} 
of their interpretation, the Court of Justice of the EU addressed the concept of the general principles of law. In particular, the first mention about belonging of fundamental rights to the general principles of EU law can be found in the judgment of the Court of Justice of the EU in case Stauder v. City of Ulm ${ }^{53}$. Further on, having developed that doctrine in case Internationale Handelsgesellschaft mbH $v$ Einfuhr- und Vorratsstelle für Getreide und Futtermittel, the Court proclaimed that respect for fundamental human rights constitutes an integral component of the general principles of EU law ${ }^{54}$.

Later in case J. Nold, Kohlen- und Baustoffgroßhandlung $v$ Commission of the European Communities the Court of Justice of the EU stressed that fundamental rights constitute an integral part of the general principles of European Union law. Under that judgment, to protect them the Court should derive enthusiasm from constitutional traditions that are common for the Member States and may not support activities incompatible with the fundamental rights set and guaranteed by the Constitutions of those states. International treaties of the Member States on the protection of fundamental rights under which the Member States cooperate or to which they are parties may serve as guidance within the law of the Community ${ }^{55}$.

Still, with time, in case Gabrielle Defrenne v Société anonyme belge de navigation aérienne Sabena the Court of Justice of the EU stated that respect for fundamental human rights is one of the general principles of law of the European community, compliance with which it shall guarantee ${ }^{56}$.

The above formulations gave grounds for some scholars to point out the principle of respect for fundamental rights ${ }^{57}$. While other scholars prove availability of the principle of protection of basic rights in EU law ${ }^{58}$.

\footnotetext{
53 Judgment of 12 November 1969, Erich Stauder v City of Ulm, Case 29-69, ECLI:EU:C:1969:57.

${ }^{54}$ Judgment of 17 December 1970, Internationale Handelsgesellschaft mbH v Einfuhr- und Vorratsstelle für Getreide und Futtermittel, Case 11-70, ECLI:EU:C:1970:114.

${ }^{55}$ Judgment of 14 May 1974, J. Nold, Kohlen- und Baustoffgroßhandlung v Commission of the European Communities, Case 4-73, ECLI:EU:C:1974:51.

56 Judgment of 15 June 1978, Gabrielle Defrenne v Société anonyme belge de navigation aérienne Sabena, Case 149/77, ECLI:EU:C:1978:130.

${ }^{57}$ Право Свропейського Союзу : навчальний посібник / За ред. Р.А. Петрова. 5-те видання, змінене і доповнене. Київ : Істина, 2013. С. 40; Лесько Т.В. Захист прав людини в Європейському Союзі URL: https://conferences.vntu.edu.ua/index.php/all-hum/all-hum-2018/paper/download/4269/3536; Митник О. Європейська інтеграція та права людини в Україні: нові виклики та перспективи. Сучасні виклики украӥнського права в контексті європейської інтеграиії : тези доповідей учасників постійно діючого наукового семінару 29 квітня 2016 р. / за заг. ред. проф. Р.С. Мельника. Бюлетень № 1 (1) квітень 2016 р. C. 9. URL: http://zdr.knu.ua/images/libraryfiles/2.pdf; Бандас Д. Захист прав людини в Європейському Союзі. Економіка України в умовах глобалізації і регіоналізащії : зб. тез доп. Міжнар. наук.-практ. конф. студ. та молод. вчених (м. Тернопіль, 3-4 квіт. 2014 р.) / редкол. : С.В. Гродський, Ю.П. Гуменюк, М.А. Живко та ін. ; відп. за вип. Є.В. Савельєв. Тернопіль : THЕУ, 2014. С. 154-158. URL: http://dspace.tneu.edu.ua/bitstream/316497/17190/1/154-158.pdf; Жукевич I. Принципи права Європейського Союзу як гарантія реалізації захисту прав і свобод людини і громадянина в Україні. Університетські наукові записки. 2009. № 1. С. 44-48; Назаренко О.А. Загальні принципи права ЄС в правовій системі СС.
} 
In our opinion, respect for human rights at the EU level should be understood as a "value of the European Union". Clarification of the nature and special features of the European Union's values and their correlation with the principles of EU law was most fully made in the thesis research by V.V. Kolesnichenko. Finally the scholar formulated his own definition of the notion "the values of the European Union". And these, in his opinion, are the general principles of EU law of the highest order (the so called "mega principles"), reflecting the basic principles shaping up legal achievements of the modern European civilization, compliance with which is ensured at a high - supranational - level. The scholar also suggests calling them principles-values and includes respect for human rights and fundamental freedoms there ${ }^{59}$.

To our belief, such differentiation is well-grounded since respect for and protection of fundamental rights constitute the necessary principal preconditions for the affirmation of fundamental rights as one of the basics of the EU system of law. At the same time, they are derivatives of those rights. Effective implementation of the principle of fundamental rights requires prior common understanding of respect for them and their further adequate protection, including judicial one.

Fundamental human rights, which thanks to judicial practice, have been acknowledged to be the general principles of EU law, were gradually enshrined in other legal acts. In particular, the 1987 Single European Act was the first founding treaty acknowledging fundamental rights ${ }^{60}$.

Still, founding treaties did not fix the list of fundamental rights. Absence of own catalogue of human rights led to the situation when the Court of Justice of the EU addressed the European Convention for the Protection of Human Rights and Fundamental Freedoms, attaching special importance to it. Thus, thanks to

Правове регулювання економіки. 2015. № 15. C. 245. URL: http://irbis-nbuv.gov.ua/cgibin/irbis_nbuv/cgiirbis_64.exe?C21COM=2\&I21DBN=UJRN\&P21DBN=UJRN\&IMAGE_FILE_DOWNLOA $\mathrm{D}=1 \&$ Image_file_name=PDF/pre_2015_15_23.pdf.

${ }^{58}$ Christopher McCrudden and Sacha Prechal. The Concepts of Equality and Non-Discrimination in Europe: A practical approach. EUROPEAN NETWORK OF LEGAL EXPERTS IN THE FIELD OF GENDER EQUALITY : European Commission Directorate-General for Employment, Social Affairs and Equal Opportunities Unit G.2; 2009. P. 4; Право Європейського Союзу : навчальний посібник / За ред. Р.А. Петрова. 5-те видання, змінене і доповнене. Київ : Істина, 2013. С. 70; Толкачова Н.Б. Принцип захисту основних прав людини у практиці Суду Європейських Співтовариств. Держава і право. 2009. Вип. 46. С. 532. URL: http://dspace.nbuv.gov.ua/bitstream/handle/123456789/9075/93-Tolkachova.pdf ?sequence=1; Стрєльцова О.В. Загальні принципи права як джерело права Європейського Союзу. Альманах права. 2012. Вип. 3. С. 268. URL: http://dspace.nbuv.gov.ua/bitstream/handle/123456789/63930/ 55-Streltsov.pdf?sequence=1.

59 Колесніченко В.В. Принципи права Європейського Союзу: загальнотеоретичне дослідження : автореф. дис. на здобуття наук. ступеня канд. юрид. наук : спец. 12.00.01. «Теорія та історія держави і права; історія політичних і правових учень». Одеса, 2010. С. 10.

60 Толкачова Н.Б. Принцип захисту основних прав людини у практиці Суду Європейських Співтовариств. Держава і право. 2009. Вип. 46. С. 536. URL: http://dspace.nbuv.gov.ua/bitstream/handle/ 123456789/9075/93-Tolkachova.pdf?sequence=1. 
the pragmatic approach of the European institutions, the Convention became a convenient tool for protecting human rights, which was general for all the EU Member States, and played an important role at all the stages of the establishment and development of the system of protection of human rights in the EU, having been transformed into an important factor of the integration processes taking place in Europe. For example, only within the period of 1975 and 1998 the Court of Justice of the EU cited the Convention in more than 70 of its judgments ${ }^{61}$.

At the level of the European Union the idea of own incorporation of the provisions on fundamental rights was realized only in 2000, through approval of the Charter of Fundamental Rights of the EU. In spite of the fact that the Charter did not set any formal legal commitments, the Court of Justice of the EU used it to interpret the general principles of law and take it into account as the guidance for interpreting the Community's legislation. And the European Parliament stressed that though the Charter did not aim to establish and fix new rights, it still clearly reflects the European legal regulation standards ${ }^{62}$. When the Treaty of Lisbon came into effect, the provisions of the Charter became binding.

The Charter enshrines many labour rights. In particular, prohibition of forced labour (Article 5), freedom of association (Article 12), right to education and vocational training (Article 14), freedom to choose an occupation and right to engage in work (Article 15), non-discrimination (Article 21), equality between women and men (Article 23), workers' right to information and consultation within the undertaking (Article 27), right of collective bargaining and action (Article 28), right of access to placement services (Article 29), protection in the event of unjustified dismissal (Article 30), fair and just working conditions (Article 31), prohibition of child labour and protection of young people at work (Article 32), right to reconciliation of family and professional life (Article 33) and right to social security and social assistance (Article 34).

However, it cannot be left unnoticed that the selection of labour rights acknowledged by the Charter as fundamental is somewhat chaotic and even accidental. And even in spite of the absence of a certain degree of commonness and their general abstract nature, these rights have a considerable effect on the development of the labour legislation of the Community.

61 Исполинов А.С. Поиск баланса между свободами внутреннего рынка и правами человека в судебной практике ЕС. Журнал зарубежного законодательства и сравнительного правоведения. Јоитпаl of foreign legislation and comparative law. 2012. № 6. C. 40. URL: http://www.nbpublish.com/ library_get_pdf.php?id=22795.

${ }^{62}$ European Parliament resolution on the impact of the Charter of Fundamental Rights of the European Union and its future status (2002/2139(INI)), O.J. 11 December 2003, C300E/432. URL: https://eur-lex.europa.eu/legalcontent/EN/ALL/?uri=CELEX\%3A52002IP0508. 
Thus, the Charter sets the general principles of EU labour law, that are of practical importance in the context of interpretation of other legal acts.

During the development of the EU Charter of Fundamental Rights the idea of the basic minimum of rights was used, that enabling some scholars to point out the principle of the basic minimum of social rights as one of the principles of EU labour law ${ }^{63}$. Meaningful expression of this principle lies in the fact that at the level of the European Union the list of minimum requirements is set for legal regulation of hired labour relations. Compliance with those supranational provisions is guaranteed by each EU Member State, and the scope of opportunities for the participants of labour relations cannot be reduced, but only expanded. Such statement is based on p. 2 of Art. 153 of the Treaty on the functioning of the European Union, that authorized European institutions to introduce minimum requirements for the conditions of work through approval of the necessary directives. Thus, legal provision of labour relations at the EU level presupposes enshrinement of the minimum scope of labour rights, that enabling to speak about the basic minimum of labour rights as about one of the key ideas (principle) of EU labour law.

\section{Equality or non-discrimination}

The next general principle of EU law is the principle of equality. It plays an important role among the basic principles of law of the European Union and was definitely developed under the influence of the concept of human rights.

Traditionally, the history of its legal development started with the Court of Justice of the European Union, since the founding treaties of the European Coal and Steel Community (1951), European Atomic Energy Community (1957), and the European Economic Community (1957) fixed only non-discrimination concerning a limited list of grounds and strived to introduce equal treatment of production factors in the internal market. And in the practice of the Court of Justice of the EU the principle of equality constitutes a component of the general principle of fundamental rights of the EU and, at the same time, - an independent general principle of law ${ }^{64}$.

Still, court recognition of the principle took place without any clear delineation between the notions "equality" and "non-discrimination", which fact

\footnotetext{
63 Дарморіс О.М. Становлення та розвиток трудового права Європейського Союзу : дис. ...канд. юрид. наук : спеціальність 12.00.05 «Трудове право; право соціального забезпечення». Одеса, 2010. C. 37-63.

${ }^{64}$ Christopher McCrudden and Sacha Prechal. The Concepts of Equality and Non-Discrimination in Europe: A practical approach. EUROPEAN NETWORK OF LEGAL EXPERTS IN THE FIELD OF GENDER EQUALITY : European Commission Directorate-General for Employment, Social Affairs and Equal Opportunities Unit. 2009. G.2, Pp.4-5.
} 
caused the affirmation of their understanding as to a certain extent synonyms ${ }^{65}$. According to the judicial practice, these are rather adjacent than differing notions.

Irregular application of the principles of equality and non-discrimination in the practice of the Court of Justice of the EU partially results from the fragmentary legal support of equality and non-discrimination at the stage of development of the European Union. At the beginning the European integration processes did not aim to introduce general equality. Hence, initially nondiscrimination referred to the field of competition and employment by such characteristics as citizenship and gender. However, later, thanks to the practice of the Court of Justice of the EU, that acknowledged double economic and social direction of the principle of equality, that principle was clearly fixed as one of the basics of the Union ${ }^{66}$. Finally, it may be stated that at the beginning of the 2000ies non-discrimination also transformed from a market integration promotion activity into a full-fledged principle of EU law. Though initially it was developed within the judicial practice, its current meaningful sense is the result of the rule-making activity of different institutions of the European Union. The interaction between market means and human rights mechanisms has transformed non-discrimination into a hybrid, but effective principle ${ }^{67}$.

All in all, now the directives at the EU level prohibit discrimination in three domains: employment, wellbeing of residents and free circulation of goods and services.

The main goal of non-discrimination activities, at the stage of their development, was implementation of the common market with the conditions of fair competition, that is integration of national markets and ensuring freedom of movement for workers. And non-discrimination initially referred to the field of competition and employment by such characteristics as citizenship and gender. However, proclamation by the Court of Justice of the EU of the general nondiscrimination principle caused the loss of its exceptionally economic expression. In this sense the principle which is further advocated by the Court of Justice of the EU approaches high level of equality protection in the EU, since the range of situations and entities subject to being protected is considerably

\footnotetext{
65 Goga G.L. General Principle of non Discrimination and Equal Treatment in the Legislation and Jurisprudence of the Court of Justice of the European Union. Acta universitatis Danubius, 2013. Vol. 5, No. 1/2013, p. 138.

${ }^{66}$ Judgment of 8 April 1976, Gabrielle Defrenne v Société anonyme belge de navigation aérienne Sabena, Case 43-75, ECLI:EU:C:1976:56; Judgment of 26 June 2001, Susanna Brunnhofer v Bank der österreichischen Postsparkasse AG, Case C-381/99, ECLI:EU:C:2001:358; Judgment of 17 September 2002, A. G. Lawrence and Others v Regent Office Care Ltd, Commercial Catering Group and Mitie Secure Services Ltd., Case C-320/00, ECLI:EU:C:2002:498.

${ }^{67}$ Xenidis Raphaële. European Regulatory Private Law: The Transformation of European Private Law from Autonomy to Functionalism in Competition and Regulation (ERPL). EUI Working Paper. LAW 2017/04 P. 24.
} 
expanded and is not now limited by the EU legislation stricto sensu ${ }^{68}$. Therefore, the general principle of non-discrimination is a powerful tool in the hands of the justices of the Court of Justice of the EU for fighting inequality.

Recognition of the principle of equality by the Court of Justice of the EU as one of the general principle of EU law, and non-discrimination - as the principle of law and a part of "fundamental individual human rights" it aims to protect" does not cause any discrepancies, but rather gives an idea about specific application of the general principle of equality.

The current understanding of the principle of equality constitutes a reflection of the judicial interpretation of the provisions of the EU legal acts in those matters. It presupposes equal treatment of all individuals, unless there exist any objective grounds for the opposite, and is expressed via ensuring equality or non-discrimination. For instance, discrimination is confirmed in case of unequal treatment of categories of people similar from the actual and legal points of view, or, vice versa, when different groups are treated in the same way ${ }^{70}$. Still, not all cases of different treatment presuppose protection. The circumstances characterizing the attitude to some groups of persons should be adequate for comparison purposes. For instance, one may compare all the employees of one employer or employees of different employers, for whom collective agreements of several companies are valid or if the parent company sets the conditions of work for all its branches on a centralized basis.

The study of legal acts of the EU in the issues of equality and the judicial practice of applying the principles of equality and non-discrimination have enabled to trace many points of contact between them. In spite of the fact that equality and non-discrimination are guaranteed and ensured by different articles of the acts of primary and secondary law of the EU, still these are two integral parts of one principle ${ }^{71}$. Therefore, they are sometimes used as synonyms ${ }^{72}$, sometimes the relationship between them is mentioned ${ }^{73}$, and sometimes they are differentiated ${ }^{74}$.

\footnotetext{
68 Xenidis R. European Regulatory Private Law: The Transformation of European Private Law from Autonomy to Functionalism in Competition and Regulation (ERPL). EUI Working Paper LAW, 2017/04. P. 17.

${ }^{69}$ Bell M. The principle of equal treatment: widening and deepening, in The evolution of EU law, Oxford, OUP. 2010. P. 611. URL: http://www.tara.tcd.ie/bitstream/handle/2262/73140/The\%20principle\%20of $\% 20$ equal $\% 20$ treatment.pdf; sequence $=1$.

70 Judgment of 14 April 1994, A. v Commission of the European Communities, Case T-10/93, ECLI:EU:T:1994:39.

${ }^{71}$ Goga G.L. General Principle of non Discrimination and Equal Treatment in the Legislation and Jurisprudence of the Court of Justice of the European Union. Acta universitatis Danubius, Vol. 5, No. 1/2013. P. 138.

72 Право Свропейського Союзу : навчальний посібник / За ред. Р.А. Петрова. 5-те видання, змінене і доповнене. Київ : Істина, 2013. С. 70; Стрєльцова О.В. Загальні принципи права як джерело права Європейського Союзу. Альманах права. 2012. Вип. 3. С. 268.

${ }^{73}$ Plender R. Equality and Non-Discrimination in the Law of European Union. 7 Pace Int'1 L. Rev., 57. 1995, P. 57. URL: http://digitalcommons.pace.edu/pilr/vol7/iss1/2.
} 
Analysis of numerous publications of Ukrainian and foreign researchers of European Union law testifies to the variety of doctrinal approaches to the understanding and correlation between equality and non-discrimination. Still, common and unchanging for them remains the understanding of the principle of equality of EU law through the requirement for an absolutely equal treatment of individuals in similar situations, but for cases when there is an objective excuse for the difference in treatment. Gradual rejection of the legal approach based on exceptionally the negative duty of "non-discrimination" can be traced, while the positive duty to promote equality is rather expanding its boundaries. That is, liquidation of discrimination and equality promotion are two sides of the same coin.

In this context it should be stressed that the principle of equality, presupposing elimination of any discrimination, started its functioning in the law and order of the EU right from the field of hired labour, while judicial practice initially referred to violations of labour rights. And it was from there that it started being applied to other societal relations.

The practice of the Court of Justice of the EU concerning non-discrimination in the field of employment is substantial. In particular, there have been many cases considered by the EU Court of Justice concerning unequal treatment of employees due to nationality or gender, and lately also due to sexual orientation, disability or ethnic origin. For example, it has been confirmed in the judicial procedure that an employer may not publicly announce discriminatory conditions of employment ${ }^{75}$. Also, the notion of disability has been expanded on to the excessive weight of employees discriminated due to obesity ${ }^{76}$. While deprivation of same-sex partners of access to employment-related benefits and services was assessed by the EU Court of Justice as admissible actions ${ }^{77}$. Also, the ban for the employees to show visible political, philosophic or religious characteristics at their workplace was also sanctioned ${ }^{78}$.

\footnotetext{
73 Judgment of 27 October 1976, Vivien Prais v Council of the European Communities, Case 130-75, ECLI:EU:C:1976:142.

74 Дашковська О.Р. Міжнародні механізми забезпечення принципу недискримінації. Актуальні проблеми сучасного міжнародного права : зб. наук. ст. за матеріалами I Харк. міжнар. прав. читань, присвяч. пам'яті проф. М.В. Яновського і В.С. Семенова, Харків, 27 листоп. 2015 р.: у 2 ч. Харків, 2015. Ч. 1. C. 123 .

${ }^{75}$ Judgment of 10 July 2008, Centrum voor gelijkheid van kansen en voor racismebestrijding v Firma Feryn NV, Case C-54/07, ECLI:EU:C:2008:397.

76 Judgment of 18 December 2014, Fag og Arbejde (FOA) v Kommunernes Landsforening (KL), Case C-354/13, ECLI:EU:C:2014:2463.

77 Judgment of 17 February 1998, Lisa Jacqueline Grant v South-West Trains Ltd., Case C-249/96, ECLI:EU:C:1998:63.

78 Judgment of 14 March 2017, Samira Achbita and Centrum voor gelijkheid van kansen en voor racismebestrijding v G4S Secure Solutions NV, Case C-157/15, ECLI:EU:C:2017:203.
} 
The mechanisms of implementation of the equality principle in the field of labour law are introduced in three directions, viz. ensuring equality (nondiscrimination) by such characteristics as race, ethnic origin; by such characteristics as religion or beliefs, disability, age, sexual orientation; and social security.

In general, in EU labour law two groups of non-discrimination can relatively be pointed out. The former embraces the criteria of prohibition, related to certain special features of an individual. These, in particular, are envisaged by Directive of the Council 2000/43/EC, Directive of the Council 2000/78/EC, Directive of the European Parliament and the Council 2006/54/EC, and Directive of the Council 2004/113/EC as of December 13, 2004.

The second group of prohibitions presupposes anti-discrimination protection of the people employed in untypical conditions of work and is valid for employees of temporary employment agencies (Directive 2008/104/EC on temporary agency work ${ }^{79}$ ); those working part-time (Directive of the Council 97/81/EC concerning the framework agreement on part-time work ${ }^{80}$ ), under the fixed-term labour contract (Directive 1999/70/EC as of June 28, 1999 concerning the framework agreement on fixed-term work, concluded by ETUC, UNICE and CEEP (the European Trade Union Confederation, the Union of Industrial and Employers' Confederations of Europe, and the European Centre of Employers and Enterprises Providing Public Services and Services of General Interest ${ }^{81}$ ), or on a remote basis (Framework Agreement on Telework ${ }^{82}$ ). The rules for this group differ from the first one, since they are not related to personal characteristics of employees but require non-discrimination in relation to individuals who have concluded labour contracts of a certain type.

\section{The general principles of EU law and communautaire labour law: summary}

The above analysis proves that modern labour law of the EU has largely been developed in accordance with the general principles of EU law. Moreover, these principles do not just guide legal regulation of labour relations, but also

\footnotetext{
${ }^{79}$ Directive 2008/104/EC of the European Parliament and of the Council of 19 November 2008 on temporary agency work OJ L 327, 5.12.2008, pp. 9-14. URL: https://eur-lex.europa.eu/legal-content/EN/ALL/ ?uri=CELEX\%3A32008L0104.

${ }^{80}$ Council Directive 97/81/EC of 15 December 1997 concerning the Framework Agreement on part-time work concluded by UNICE, CEEP and the ETUC. Annex : Framework agreement on part-time work OJ L 14, 20.1.1998, pp. 9-14. URL: https://eur-lex.europa.eu/legal-content/EN/TXT/?uri=CELEX\%3A31997L0081.

${ }^{81}$ Council Directive 1999/70/EC of 28 June 1999 concerning the framework agreement on fixed-term work concluded by ETUC, UNICE and CEEP OJ L 175, 10.7.1999, pp. 43-48. URL: https://eur-lex.europa.eu/legalcontent/GA/TXT/?uri=CELEX:31999L0070.

${ }^{82}$ Framework agreement on telework, signed by the European social partners ETUC (and the liaison committee Eurocadres-CEC), UNICE, UEAPME and CEEP on 16 July 2002. URL: https://www.businesseurope.eu/sites/buseur/files/media/imported/2006-01428-EN.pdf.
} 
determine the trends in the development of EU labour law. And they also characterize the basics of interaction of the norms of communautaire and national labour law. They affect, though, the essence and regularities of EU labour law development in different ways. In particular, the principles of the rule of law, legal certainty, proportionality and subsidiarity concerning employment function almost in the same way as in relation to other societal relations. Instead, fundamental rights and equality as general principles of EU law have a double effect on the legal regulation of hired labour relations, since they express, besides, common communautaire ones, also specific qualifying characteristics of EU labour law.

\section{Sectoral principles of EU labour law}

Legal regulation of labour relations is subordinated not only to the general principles of EU law, but also to the principles inherent in EU labour law. The latter differentiate it from other branches of law and are, in a way, fundamental ideas constituting the basis of EU labour law and expressing its essence.

In Ukrainian labour law science the first attempt to comprehensively research and describe the principles of EU labour law were made in 2010 by O.M. Darmoris ${ }^{83}$. Having analyzed the legal acts of the EU and the scientific achievements of foreign scholars, the author points out four groups of principles of EU labour law. Namely, these are the principles reflected in the international and regional labour acts and embodied in the labour law; the principles that got their actual meaning, their "second breath" in EU labour law; the principles characteristic of labour law as a component of the EU's social policy; the principles (qualifying characteristics) inherent in labour law as a part of the legal system of the $\mathrm{EU}^{84}$.

The first group of principles, in her opinion, is made up of the fundamental provisions reflected in international and regional acts on labour and embodied in labour law of the European Union. These, in particular, include freedom of labour and prohibition of forced labour; prohibition of child labour; freedom of association; the right of social partners to negotiate and conclude collective agreements; equality and non-discrimination; the right to fair and safe conditions of labour, the right to fair remuneration, ensuring sufficient living standard for employees and their family members; the right to fair treatment at work; protection of the rights of employees; the principle of promotion ${ }^{85}$.

\footnotetext{
83 Дарморіс О.М. Становлення та розвиток трудового права Європейського Союзу : дис. ... канд. юрид. наук : спеціальність 12.00.05 «Трудове право; право соціального забезпечення». Одеса, 2010. C. 37-64.

${ }^{84}$ Ibid. C. 8 .

${ }^{85}$ Ibid. C. 46.
} 
All the principles referred to the first group by O.M Darmoris, in spite of some editorial differences, duplicate the list of rights enshrined in the EU Charter of Fundamental Rights, and hence constitute the general principles of EU law in general and labour law in particular. In our opinion, reflection of the respective list of rights in international or regional labour acts primarily points to the sources that constituted the basis for the construction and meaningful development of the principles of EU labour law. However, economic and social factors of the European integration processes have changed and modified the essence of the respective principles with respect to the goal of the EU establishment. Having undergone significant changes, the respective basic provisions now constitute the grounds for the development of supranational legal regulation of labour relations. They also determine its essence and content.

The second group of principles that got their actual meaning or "second breath" in EU labour law, according to O.M. Darmoris, includes the principle of free movement of employees. In fact, the freedom of movement of persons, of which the principle of free movement of workers is a constituent, has got a special manifestation in European Union law. First of all, this is the invention of the European integration process and it is still guiding the development of EU law.

Thus, since the period of establishment of European economic communities and up till now the freedom of movement of workers still is one of the key principles of the EU functioning, enshrined in its founding treaties. In the current version of the Treaty on the functioning of the European Union Section 1 of Title 4 "Free Movement of Persons, Services and Capital" is dedicated to the issue of free movement of individuals between states. Under Art. 45 of the Treaty on the functioning of the European Union, within the European Union free movement of workers is ensured through prohibition of any discrimination on the basis of nationality (citizenship) in relation to employees who are citizens of the EU Member States, in the issues of employment, labour remuneration as well as other conditions of labour.

Under the Treaty on the functioning of the European Union, the freedom of movement for employment purposes presupposes the right:

1) to accept actually made employment proposals;

2) to freely move within the territories of the Member States for further employment purposes;

3) to stay in the territory of a Member State for employment purposes in line with the provisions regulating employment of citizens of this state, determined in laws, by-laws and administrative acts;

4) to stay in the territory of a Member State after labour relations are terminated. 
The above provisions are partially duplicated in Article 15 of the EU Charter of Fundamental Rights, enshrining the right to freely look for a job, to work, to exercise the right to foundation and to provide services in any Member State of the EU. Enshrinement of these rights in the Charter proves that these are not just fundamental rights but the general principles of EU law as well.

Freedom of movement of workers is one of the cornerstones of the European integration. That is why gradually its content became more general than it was initially devised, and was supplemented with equal treatment provisions ${ }^{86}$. That presupposes elimination of any discrimination by the citizenship characteristic in relation to employment, labour remuneration and other conditions of work and employment. That means that migrant employees are entitled to the same labour remuneration and conditions of work in the Member State where they work as the ones applied to the citizens of that Member State. Provisions of collective or individual labour contracts, running counter to such nondiscrimination by citizenship, are legally invalid ${ }^{87}$.

At the same time, absolute non-discrimination by citizenship corresponds to legal guarantees for the citizens of the Member States that accept employees from other states for employment purposes. According to the clarifications provided by the Court of Justice of the EU, the respective provisions of the founding treaties need to be interpreted as the ones also fixing the guarantees of local employees against negative consequences that may possibly be caused by employment of citizens of other Member States on the terms and with the labour remuneration that are less beneficial than the terms that need to be complied with under the national legislation of the employing country. Thus, the interpretation provided by the Court of Justice has laid down the grounds for the principle according to which the workers of the accepting Member States should not be faced with the risk of competition on the part of cheap foreign labour force ${ }^{88}$. In the opinion of the Court, free movement of workers requires not just ensuring of equal access to employment for citizens of other Member States in each state, but also provision of guarantees for its own citizens for the sake of preventing unfavorable consequences that may be caused by employment of foreigners ${ }^{89}$.

\footnotetext{
${ }^{86}$ Susanne K. Schmidt, Michael Blauberger \& Dorte Sindbjerg Martinsen. Free movement and equal treatment in an unequal union, Journal of European Public Policy, 2018. 25:10, pp. 1391-1402. DOI: 10.1080/13501763.2018.1488887.

${ }^{87}$ Regulation (EU) No 492/2011 of the European Parliament and of the Council of 5 April 2011 on freedom of movement for workers within the Union Text with EEA relevance. URL: https://eur-lex.europa.eu/legalcontent/en/TXT/?uri=CELEX:32011R0492.

${ }^{88}$ Stein Evju. "Revisiting the Posted Workers Directive: Conflict of Laws and Laws in Contrast", in C. Barnard and O. Odudu (eds.) The Cambridge Yearbook of European Legal Studies, Vol. 12, 2009-2010, P. 153. URL: https://www.researchgate.net/publication/305942091_Revisiting_the_Posted_Workers_Directive_ Conflict_of_Laws_and_Laws_in_Contrast.

${ }^{89}$ Judgment of 4 April 1974, Commission of the European Communities v French Republic, Case 167-73. URL: http://curia.europa.eu/juris/showPdf.jsf?text=\&docid=88640\&pageIndex=0\&doclang=EN\&mode=lst \& $\operatorname{dir}=\&$ occ $=$ first $\&$ part $=1 \&$ cid $=7444244$.
} 
Taking the above into account, we consider that free movement of workers should be considered in two dimensions: viz, as a fundamental economic freedom and a fundamental right. Such double status enables to combine the effect of the European market principles and socially guided basics of legal regulation. Taking this into account, the freedom of free movement of workers as the general principle of EU law and one of the basics for the construction of this community affects not just development of legal regulation of hired labour relations but other social relations as well. Thanks to it, the fundamental ideas that further guide EU law towards social development are borrowed from labour law. In such interpretation, the effect of this principle is reverse since, being developed for the field of employment, it has expanded its effect onto other fields of EU competence.

Freedom of movement of workers as the key economic freedom and the principle of EU labour law is located at the cross-roads of legal norms and economic interests. This stipulates its double direction. To be more specific, social, economic and cultural engagement of workers in the society of the Member States where they have got a job as well as promotion of the development of the EU domestic market through the possibility of worker movement to areas with shortage of labour force or in search of better opportunities. Thus, many people get more employment opportunities with due account of their skills, avoiding densely saturated places in the labour market.

\section{Collective labour rights as the principles of EU labour law}

The next principles of labour law of the European Union refer to the legal provision of collective labour relations. They are manifested through the freedom of association and a number of collective rights of social partners enshrined in the provisions of the primary and secondary EU law.

At the same time, it should be pointed out that Article 153 of the Treaty on the functioning of the European Union excludes from the Union's competences settlement of the issues related to the right to association, the right to strike, or the right to apply lockout. And still, in spite of all this, Article 12 of the EU Charter of Fundamental Rights presupposes that everybody has the right to freedom of peaceful assembly and freedom of association at all levels, in particular, in trade union matters, including the right of everyone to establish trade unions and to join them for the sake of protecting his/her interests. Such wording also embraces the rights to participate in trade union's activity ${ }^{90}$. The above mutually exclusive provisions are a bit confusing.

\footnotetext{
${ }^{90}$ Brian Bercusson. Freedom of assembly and of association (Article 12) in European labour law and the EU Charter of Fundamental Rights - summary version - European Trade Union Institute (ETUI) Brussels, 2002. P. 27.
} 
A way out has been suggested by a well-known researcher of labour law B. Bercusson. In particular, he advises to resort to a supernarrow interpretation of the respective provision of the Treaty of Lisbon and to understand it as the one not preventing from the implementation of the freedom of association, which is at the same time acknowledged by the Charter of the Fundamental Rights of the EU. And he suggests that it should generally be further excluded ${ }^{91}$.

Finally, Article 153 of the Treaty on the functioning of the European Union sets it that informing and consulting of employees, representation and collective protection of the interests of employees and employers, including the right of employees to take part in join management, belong to the joint competence of the European Union. The respective provisions are further developed by the Charter of Fundamental Rights. Thus, Article 27 of the Charter states that employees and their representatives should have adequate guarantees of timely obtaining of information and consultations in cases and on the terms envisaged by the EU legislation as well as national legislation and practice.

Encouragement of cooperation between the Member States and promotion of coordination of their activity in the issues related to the right to freedom of association and collective bargaining between employers and hired workers constitute a duty of the European Commission (Art. 156 of the Treaty on the functioning of the European Union). And the very collective labour rights are enshrined in the EU Charter of Fundamental Rights, which fact automatically assigns the status of general principles of EU law to them. For instance, Article 28 of the Charter sets it that employees and employers or their organizations, in accordance with the legislation of the Union, as well as national legislation and practice shall be entitled to hold negotiations on a proper level and to conclude collective agreements and, in case of conflict of interests, - to resort to collective actions for the sake of protecting their interests, in particular, to go on strike.

Thus, the practice of collective negotiations is reinforced by the provisions of acquis communautaire. The latter, in particular, refer to the process of holding collective negotiations, expression of the results of negotiations in the form of a collective agreement, composition of subjects and levels of negotiations. Such conclusion can be drawn on the basis of Article 28 of the Charter, which presupposes exercising of the right to collective bargaining in two stages, which are initiation and holding of negotiations as well as their completion through collective agreement conclusion ${ }^{92}$.

\footnotetext{
${ }^{91}$ Ibid.

${ }^{92}$ Bruno Veneziani. Right of collective bargaining and action (Article 28) in European labour law and the EU Charter of Fundamental Rights - summary version - European Trade Union Institute (ETUI) Brussels, 2002. P. 54.
} 
Legal acts of the EU allow the representatives of employees and employers to take an active part in the regulation of hired labour relations. For example, under Article 153 of the Treaty on the functioning of the European Union, the Member States may entrust employers and hired employees, at their joint request, with enforcement of directives or decisions of the Council. Besides that, many directives contain reservations concerning the possibility for deviating from their provisions through collective agreement conclusion ${ }^{93}$.

The above provisions of the EU legislation are based on the conclusions once made by the EU Court of Justice. In particular, freedom of trade union activity, that includes the right of employees to establish associations without any impediments at their own discretion as well as the right of such associations to enjoy all legal remedies to protect their members, was acknowledged by the EU Court of Justice back in 1990 to be the general principle of EU labour law (case Maurissen and another $v$ Court of Auditors (Joined Cases C-193/87 \& $\left.C-194 / 87)^{94}\right)$. That happened even before the respective provisions were enshrined in the EU Charter of Fundamental Rights.

The EU Court of Justice has also contributed to the affirmation of other collective labour rights. For example, in case Laval un Partneri Ltd (Case C$341 / 05$ ) the fundamental right to collective actions is recognized as an integral part of the general principles of law ${ }^{95}$. And in case Viking Line (Case C-438/05) the right to strike is recognized as the one ${ }^{96}$. Belonging of the right to take part in collective bargaining to the general principles of EU law is stressed in the judgment of the Court of Justice in case European Commission v Federal Republic of Germany (Case C-271/08) ${ }^{97}$.

The principle of collective representation of employees has become one of the fundamental principles of EU labour law after consideration of case Commission of the European Communities $v$ United Kingdom of Great Britain and Northern Ireland (Case C-382/92), in which the effect of the employers' commitment to inform and consult employees was spread on to their representatives ${ }^{98}$. And in case Albany International BV v Stichting Bedrijfspensioenfonds Textielindustrie (Case C-67/96) on the compatibility of provisions of collective agreements with

\footnotetext{
93 European Industrial Relations Dictionary. Collective industrial relation. URL: https:// www.eurofound.europa.eu/es/european-industrial-relations-dictionary-collective-industrial-relations\#.

94 Judgment of 18 January 1990, Henri Maurissen and European Public Service Union v Court of Auditors of the European Communities, Joined cases C-193/87 and C-194/87, ECLI:EU:C:1990:18.

95 Judgment of 18 December 2007, Laval un Partneri Ltd v Svenska Byggnadsarbetareförbundet, Case C-341/05, OJ C 281, 12.11.2005.

${ }^{96}$ Judgment of 11 December 2007, International Transport Workers' Federation and Finnish Seamen's Union v Viking Line ABP and OÜ Viking Line Eesti, Case C-438/05, ECLI:EU:C:2007:772.

97 Judgment of 15 July 2010, European Commission v Federal Republic of Germany, Case C-271/08, ECLI:EU:C:2010:426.

${ }^{98}$ Judgment of 8 June 1994, Commission of the European Communities v United Kingdom of Great Britain and Northern Ireland, Case C-382/92, ECLI:EU:C:1994:233.
} 
competition rules, the EU Court of Justice confirmed exclusion of collective agreements from the area of effect of the EU competition law ${ }^{99}$.

Thus, collective labour rights recognized in the judicial practice and enshrined in the EU Charter of Fundamental Rights belong to the general principles of EU labour law. Still, they were thus enshrined in a somewhat chaotic way. Finally, there is no common standpoint concerning the spectrum of collective labour rights as the principles of EU labour law. For example, B. Bercusson includes to the principles of EU collective labour law collectively agreed labour standards, representation of collective interests of hired employees, participation of employees in the decision-making and collective protection of labour rights ${ }^{100}$. $\mathrm{S}$.Yu. Kashkin points out the right of workers to collective bargaining and to conclusion of collective agreements as the basis for social partnership in the context of provisions of the EU Charter of Fundamental Rights ${ }^{101}$. And Ukrainian researcher of EU labour law O.M. Darmoris writes about such important principles of labour law as the right of social partners to bargain and to conclude collective agreements, as well as about the principle of freedom of association $^{102}$.

The principles of freedom of association, the right to collective bargaining and to collective agreement conclusion, the right to participate in company management as well as the right to protection of collective rights and interests are clarified by T.V. Shepliakova in her papers ${ }^{103}$.

Analysis of the provisions of the EU legal acts, judicial practice and doctrinal elaborations allows to state that the system of collective labour rights as the general principles of EU labour law is made of the right of collective bargaining and action, the right of workers to information and consultation within the undertaking as well as freedom of assembly and association. Thus, the right to enter trade unions as well as the right not to take part in a trade union, independence of trade union organization, the right to representation of collective interests, information and consultation of workers, the right to take part in collective bargaining, the right to collective action and the right to strike constitute the general principles of EU labour law. While the need for cooperation between social partners is recognized as one of the basics of EU

\footnotetext{
99 Judgment of 21 September 1999, Albany International BV v Stichting Bedrijfspensioenfonds Textielindustrie, Case C-67/96, ECLI:EU:C:1999:430.

${ }^{100}$ BERCUSSON B. EUROPEAN LABOR LAW IN CONTEXT: A REVIEW OF THE LITERATURE. EUROPEAN LAW JOURNAL, VOLUME 5, ISSUE 2, JUNE 1999. P. 318.

101 Хартия ЕС об основных правах / под ред. д. ю. н., проф. С.Ю. Кашкина. Москва : Юриспруденция, 2001. С. 107.

102 Дарморіс О.М. Становлення та розвиток трудового права Європейського Союзу : дис. ...канд. юрид. наук : спеціальність 12.00.05 «Трудове право; право соціального забезпечення». Одеса, 2010. C. $50-51$.

${ }^{103}$ Шеплякова Т.В. Колективні трудові права працівників за законодавством СС. Часопис Київського університету права. 2013. № 4. C. 376-379. URL: http://nbuv.gov.ua/UJRN/Chkup_2013_4_92.
} 
labour law. And respective interaction is ensured through enshrinement of collective rights and the procedures for their implementation.

\section{The principles of labour law of Ukraine: how significant are the divergences with the EU?}

It should be pointed out that the current Labour Code does not contain any specific article, which would stress the principles of legal regulation of labour relations on the legislative level. It is considered that such principles can be identified through analysis of the content of labour law norms in general as the integral legal structure. Therefore, different authors have provided different interpretations of some fundamental ideas on which labour law as the branch of Ukrainian law is based ${ }^{104}$. Or, taking into account the Constitution of Ukraine and its articles that proclaim basic social rights of citizens, they have presented them as labour law principles. The right to labour, occupational safety, the right to fair labour remuneration, the right to rest, etc., are, in particular, considered to be such ones.

As it can be seen, even such a short list of principles of modern labour law of Ukraine clearly illustrates their relation to the fundamental ideas available in the already mentioned EU Charter of Fundamental Rights. And if Article 43 of the Constitution of Ukraine, which is dedicated to the right to work, is analyzed in greater detail, other norms that are of fundamental importance and belong to labour rights enshrined by the Charter can be found: prohibition of compulsory labour, freedom of choice of profession, non-discrimination, fair and decent conditions of work, etc. If other articles of the Fundamental Law of Ukraine are analyzed, a number of other similar principles coinciding with the list the Charter contains can be found. These are freedom of association, the right to education, equality of women and men, prohibition of child labour, the right to social security and social care.

That is, if the principles of labour law are deduced from the content of basic social rights of individuals and citizens, complete correspondence of Ukraine's labour law principles to the principles of EU labour law could be stated ${ }^{105}$.

The authors of the draft Labour Code of Ukraine submitted to the Verkhovna Rada of Ukraine, which is, most probably, to be approved by the Parliament next year, seem to have worked in this aspect.

\footnotetext{
104 Трудове право України : Академічний курс : підручник для студентів вищих навчальних закладів / П.Д. Пилипенко, В.Я. Бурак, З.Я. Козак та ін. ; за ред. П.Д. Пилипенка. 5-те вид., перероб. і доп. Київ : Видавничий Дім «Ін Юре», 2014. С. 42-43.

105 Пилипенко П.Д. Про засади інтеграції трудового права України до трудового права Європейського Союзу. Актуальні проблеми соціального права. Випуск 9. Матеріали міжнародної науково-практичної конференції «Украӥнська правнича наука та ї̈ вплив на сучасні реформи» (до 95-річчя Цигилика Теодора Івановича) 6 грудня 2019 року. Львів : «ГАЛИЧ-ПРЕС», 2020. С. 6.
} 
The key principles determining the basics of labour relationship regulation in the draft Code are as follows: 1) freedom of labour, that includes the right to labour chosen by everyone and accepted on a free basis; 2) prohibition of compulsory and child labour; 3 ) non-discrimination in the field of labour and provision for individuals who have been subjected to discrimination, the right to go to court to have the fact of discrimination acknowledged and removed, as well as reimbursement of the damages incurred as the result of discrimination; 4) ensuring complete and productive employment of workers and their protection against unemployment; 5) ensuring of the right to equal remuneration for equal-value labour; 6) ensuring the right of each worker to decent conditions of work, including conditions of work that meet the requirements set for occupational safety and hygiene, the right to rest, that includes limitation of working hours, ensuring of daily rest, days off, holidays, on which there is no work, paid annual leave; 7) equality of the rights and opportunities of workers, including gender equality, through ensuring unity and differentiation of conditions of work; 8) ensuring timely and full payment of salary to workers, minimum salary at the level necessary for ensuring sufficient living standard for oneself and one's family; 9) ensuring the right of workers to general obligatory state social insurance; 10) creation of equal opportunities for workers' professional growth, training, re-training and advanced training; 11) ensuring protection of workers against ungrounded dismissal; 12) ensuring state protection of workers against illegal dismissal; 13) combination of state and contractual regulation of labour relations; 14) ensuring the right of workers and employers to freedom of association for representation purposes and for the sake of protecting their rights and interests; 15) supervision and control over compliance with labour legislation ${ }^{106}$.

In general, as it can be seen, fifteen principles on which the labour law of Ukraine will be based have been determined. However, their comparison with the above principles of EU labour law already known to us testifies to certain non-correspondences between these two lists of the principles of legal regulation of hired labour relations. Can this be considered as a problem that will further not contribute to the integration of Ukraine's labour law into the system of EU labour law? Obviously, no, since some of the principles inherent in European labour law by their direction aim to ensure legal regulation of labour relations at the supranational level. The field of their effect is much wider and refers to the legal field of all Member States of the Community. Moreover, such principles as the principle of legal certainty, supremacy and direct effect of EU law, proportionality and subsidiarity, in fact, belong to general principles of law, and

\footnotetext{
106 Проєкт Трудового кодексу України. Книга перша. Від 24.07.2017. URL: http://search.ligazakon.ua/ 1_doc2.nsf/link1/DH1A200V.html.
} 
their enshrinement at the level of a regulatory act of an EU Member State, regulating only social labour relations at the national level, could hardly be grounded. At least, the example of the Republic of Poland in this respect is rather illustrative, since even in spite of membership in the EU the Labour Code (Kodeks pracy) of that country in Section II The Fundamental Principles of Labour Law (Podstawowe zasady prawa pracy) presupposes only some principles of labour relations regulation, available in the EU Charter of Fundamental Rights.

As far as the principle of freedom of movement (mobility) of workers, which constitutes one of the key principles of EU labour law, is concerned, already in the Association Agreement the Parties have agreed that, in line with the laws, conditions and procedures applied in the Member State and in the EU, treatment of workers who are Ukrainian citizens and are legally employed in the territory of the Member State, must be free from any discrimination by citizenship in relation to conditions of work, remuneration, or dismissal as compared to the citizens of that Member State. While Ukraine, in accordance with the laws, conditions and procedures applied in its territory shall ensure respective treatment in relation to workers who are the citizens of the Member State and are legally employed in its territory ${ }^{107}$.

Attention should specifically be paid to the principle of legal certainty, since until recently it has not been particularly popular in Ukraine's system of law, let alone its labout law. Its appearance (availability), if we rephrase J.-L. Bergel already cited by us, has been considerably affected by the judicial practice and, primarily, by the practice of the European Court of Human Rights, which while considering disputes of the citizens of Ukraine against the state of Ukraine and meeting the requirements of claimants was guided, besides others, by the principle of legal certainty, considering that application of the law in a specific situation must be predictable. Finally, both the Supreme Court and the Constitutional Court of Ukraine, while considering cases about violation of labour rights of workers, have referred to the principle of legal certainty, which is based on the idea of predictability (expectedness) of crucial legal consequences by the subject of relations.

It is court that, as it is pointed out in legal literature, has the duty to control compliance with the principle of legal certainty. In Ukraine, in particular, after the structure and the composition of the Supreme Court has been upgraded, responsibility for the development of sustainable judicial practice lies with the Grand Chamber of the Supreme Court, which among other things in cases set by

\footnotetext{
107 Угода про асоціацію між Україною, з однієї сторони, та Свропейським Союзом, Свропейським співтовариством 3 атомної енергії і їхніми державами-членами, з іншої сторони. Від 30.11.2015. URL: https://zakon3.rada.gov.ua/laws/show/984_011.
} 
law, revises court judgments during cassation proceedings, for the sake of equal application of the norms of law by courts and in particular concerning compliance with the norms of legal certainty.

If we take into account the fact that the principle of legal certainty constitutes an integral component of the principle of rule of law, which is wider in meaning, it would be absolutely logical to draw a conclusion about its belonging to Ukraine's system of law in general and labour law in particular. And that is one more confirmation of the fact that integration of the labour law of Ukraine to the same-name legal developments of the European Union is absolutely possible.

\section{CONCLUSIONS}

To sum up the above, we consider that the EU principles of labour law as the system of norms aimed to ensure hired labour relations at the EU level are the fundamental ideas of the establishment, development and functioning of EU labour law, that express the essence of the European integration processes and stem from the law of the European Union, national labour law of the EU Member States, international commitments common for all Member States, including the European Convention for the Protection of Human Rights and Fundamental Freedoms, social charters approved by the EU and the Council of Europe as well as precedent law of the Court of Justice of the European Union and the European Court of Human Rights, and determine the scope of application, procedure and conceptual orientation of legal regulation of labour relations at the supranational level.

Legal provision of hired labour relations in the European Union is ensured in accordance with the general principles of EU law (the principle of legal certainty, rule and direct effect of EU law, proportionality and subsidiarity, fundamental rights, equality) and special principles of EU labour law (freedom of free movement of workers, minimum scope of labour rights, freedom of association, the right to collective bargaining and collective action, the right of workers to information and consultation within the undertaking.

And in the legal doctrine attempts are still made to differentiate between and to group these non-uniform principles. For example, scientists are proving that the principles of the rule of law and direct effect characterize the rules of interaction of acquis communautaire with other systems of law. The principles of legal certainty, proportionality and subsidiarity differ from other fundamental principles by their functional importance. While the principles of fundamental rights and equality are related to the substantive law of the EU in general. At the same time freedom of free movement of workers and fundamental collective 
labour rights are called sectoral special principles of EU law ${ }^{108}$. Some scientists suggest focusing on the principles that are most important for EU labour law. For example, Ye.N. Yegorova considers the principles of social justice, equality, non-discrimination and equal remuneration for equal labour to be such principles $^{109}$.

In our opinion, it is inexpedient to strive for such an artificial association and grouping of the key principles of EU labour law. Let us recall that the official slogan of the European Union runs as follows: "United in diversity". Thus, to our belief, absence of any structure in the EU labour law principles will not deprive them of their value and will not diminish their importance for the legal regulation of labour relations. It is most expedient to disclose the principles of EU labour law in their interrelation, when different principles may develop or complement the content of other principles.

The variety of meaningful manifestation, forms of enshrinement and functional importance, as well as, at the same time, the unity of conceptual direction of the legal regulation of hired labour relations is a positive factor.

Already now, at the stage of Ukraine's participation in the cooperation with the European Union as an associated member, the parties envisaged in the Association Agreement the need to ensure and implement in their laws and practices the main internationally recognized labour standards, which are: a) freedom of association and effective recognition of the right to collective bargaining; b) elimination of all forms of compulsory or obligatory labour; c) actual elimination of child labour; and d) elimination of discrimination in relation to employment and professions.

Besides that, the parties confirmed their commitment concerning effective performance of the fundamental and priority conventions of ILO, ratified by them, as well as the 1998 ILO Declaration on Fundamental Principles and Rights at Work, as well as are considering the issue of ratification and implementation of other ILO conventions classified by this international organization as the ones meeting modern requirements. Therefore, it may be confidently stated that legal provision of hired labour relations both in the European Union and in Ukraine is based on common legal regulation principles that have been time-tested and have actually become an integral part of contemporary systems of law, aiming to ensure the highest social value, compliance with the rule of law, respect for human rights and fundamental freedoms of individuals.

\footnotetext{
108 Колесніченко В.В. Принципи права Свропейського Союзу: загальнотеоретичне дослідження : автореф. дис. на здобуття наук. ступеня канд. юрид. наук : спец. 12.00.01. «Теорія та історія держави і права; історія політичних і правових учень». Одеса, 2010. С. 16.

${ }^{109}$ Егорова К.Н. Основы трудового права Европейского Союза : дисс. канд. юр. наук : спец. 12.00.10 «Международное право; Европейское право». Москва, 2013. С. 34.
} 


\section{SUMMARY}

The integration process has shown that European Union intervention is needed in the legal regulation of labour relations. Therefore, it is extremely important for Ukraine, which has declared its intention to become an EU Member State, to study the basic legal provisions that are reciprocal for EU Member States in the sphere of employment. The main objectives of this article are to analyze the principles of EU labour law, their substantive content and functional orientation. First, the article describes the general principles of EU law as they are inherent in labour law as its structural element. Secondly, it examines principles that are specific only to EU labour law. The latter distinguish labour law from other branches of law and express its essence. Subsequently, the principles of labour law of Ukraine are described, and it is noted that the legal regulation of labour relations both in the European Union and in Ukraine is based on similar principles, which have withstood the test of time and have become in fact an integral part of modern legal systems.

\section{REFERENCES}

1. Угода про асоціацію між Україною, з однієї сторони, та Європейським Союзом, Свропейським співтовариством 3 атомної енергії і їхніми державами-членами, 3 іншої сторони від 30.11.2015. URL: https:// zakon3.rada.gov.ua/laws/show/984_011.

2. Бандас Д. Захист прав людини в Європейському Союзі. Економіка України в умовах глобалізащії і регіоналізащії : зб. тез доп. Міжнар. наук.практ. конф. студ. та молод. вчених (м. Тернопіль, 3-4 квіт. 2014 р.) / редкол. : С.В. Гродський, Ю.П. Гуменюк, М.А. Живко та ін. ; відп. за вип. С.В. Савельєв. Тернопіль : ТНЕУ, 2014. С. 154-158. URL: http:// dspace.tneu.edu.ua/bitstream/316497/17190/1/154-158.pdf.

3. Бержель Ж.-Л. Общая теория права. Москва, 2000. 576 с. [in Russian].

4. Брацук I.3. Теоретико-правові засади імплементації права Європейського Союзу в національне право держав-членів : монографія. / за наук. ред. проф. М.М. Микієвича. Львів : ЛНУ імені Івана Франка, 2016. $230 \mathrm{c}$.

5. Bell M. The principle of equal treatment: widening and deepening, in The evolution of EU law, Oxford, OUP, 2010. Pp. 611-639. URL: http:// www.tara.tcd.ie/bitstream/handle/2262/73140/The\%20principle\%20of\%20equal $\% 20$ treatment.pdf; sequence $=1$.

6. Bercusson B. European Labor Law in Context: A Review of the Literature. European Law Journal, Volume 5, Issue 2, June 1999. 754 p. 
7. Brian Bercusson, Freedom of assembly and of association (Article 12) in European labour law and the EU Charter of Fundamental Rights - summary version - European Trade Union Institute (ETUI) Brussels, 2002. 104 p.

8. Bruno Veneziani, Right of collective bargaining and action (Article 28) in European labour law and the EU Charter of Fundamental Rights - summary version - European Trade Union Institute (ETUI) Brussels, 2002. 104 p.

9. Витвицкая О., Горниг Г. Право Европейского Союза. СанктПетербург : Питер, 2005. 256 с.

10. Christopher McCrudden and Sacha Prechal. The Concepts of Equality and Non-Discrimination in Europe: A practical approach. EUROPEAN NETWORK OF LEGAL EXPERTS IN THE FIELD OF GENDER EQUALITY : European Commission Directorate-General for Employment, Social Affairs and Equal Opportunities Unit G.2. 2009. 60 p.

11. Council Directive 97/81/EC of 15 December 1997 concerning the Framework Agreement on part-time work concluded by UNICE, CEEP and the ETUC - Annex : Framework agreement on part-time work OJ L 14, 20.1.1998, p. 9-14. URL: https://eur-lex.europa.eu/legal-content/EN/TXT/?uri=CELEX\% 3A31997L0081.

12. Council Directive 1999/70/EC of 28 June 1999 concerning the framework agreement on fixed-term work concluded by ETUC, UNICE and CEEP OJ L 175, 10.7.1999, pp. 43-48. URL: https://eur-lex.europa.eu/legalcontent/GA/TXT/?uri=CELEX:31999L0070.

13. Дарморіс О.М. Становлення та розвиток трудового права Європейського Союзу : дис. ... канд. юрид. наук : спеціальність 12.00.05 «Трудове право; право соціального забезпечення». Одеса, 2010. 226 с.

14. Дашковська О.Р. Міжнародні механізми забезпечення принципу недискримінації. Актуальні проблеми сучасного міжнародного права : зб. наук. ст. за матеріалами I Харк. міжнар. прав. читань, присвяч. пам'яті проф. М.В. Яновського і В.С. Семенова, Харків, 27 листоп. 2015 р.: у 2 ч. Харків, 2015. Ч. 1. С. 119-127.

15. Directive 2008/104/EC of the European Parliament and of the Council of 19 November 2008 on temporary agency work OJ L 327, 5.12.2008, pp. 9-14 URL: https://eur-lex.europa.eu/legal-content/EN/ALL/?uri=CELEX\%3A3200 $8 \mathrm{~L} 0104$.

16. Энтин М.Л. Суд европейских сообществ: правовые формы обеспечения западноевропейской интеграции. Москва : Международные отношения, $1987.176 \mathrm{c}$.

17. European Industrial Relations Dictionary - Collective industrial relation. URL: $\quad$ https://www.eurofound.europa.eu/es/european-industrial-relationsdictionary-collective-industrial-relations\#. 
18. Европейское право : учебник для вузов / под общ. ред. д. ю. н., проф. Л.М. Энтина. Москва : НОРМА, 2000. 690 с.

19. Егорова К.Н. Основы трудового права Европейского Союза : дисс. канд. юр. наук : спец. 12.00.10 «Международное право; Европейское право» Москва, 2013. 174 с.

20. European Parliament resolution on the impact of the Charter of Fundamental Rights of the European Union and its future status (2002/2139(INI)), O.J. 11 December 2003, C300E/432. URL: https:// eur-lex.europa.eu/legal-content/EN/ALL/?uri=CELEX\%3A52002IP0508.

21. Framework agreement on telework, signed by the European social partners ETUC (and the liaison committee Eurocadres-CEC), UNICE, UEAPME and CEEP on 16 July 2002. URL: https://www.businesseurope.eu/ sites/buseur/files/media/imported/2006-01428-EN.pdf.

22. Goga G.L. General Principle of non Discrimination and Equal Treatment in the Legislation and Jurisprudence of the Court of Justice of the European Union. Acta universitatis Danubius, 2013. Vol. 5, No. 1/2013, Pp. 138-145.

23. Головко-Гавришева О. Принцип верховенства права Європейського Союзу як основа взаємодії правової системи $\mathrm{CC}$ і національних правових систем держав-членів. Вісник Львівського наиіонального університету. Серія Міжнародні відносини. 2017. Випуск 42. С. 227-232

24. Жукевич I. Принципи права Європейського Союзу як гарантія реалізації захисту прав і свобод людини і громадянина в Україні. Університетські наукові записки. 2009. № 1. С. 44-48.

25. Загальна теорія держави i права : підручник для студентів юридичних вищих навчальних закладів / М.В. Цвік, О.В. Петришин, Л.В. Авраменко та ін. ; за ред. М.В. Цвіка, О.В. Петришина. Харків : Право, 2009. 584 с.

26. Іванець А. Верховенство права Європейського Союзу відносно національного права держав-членів: модель реформ для України. «Гілея: науковий вісник» : збірник наукових праць. Київ, 2012. Випуск 58 (додатки).

27. Исполинов А.С. Поиск баланса между свободами внутреннего рынка и правами человека в судебной практике ЕС. Журнал зарубежного законодательства и сравнительного правоведения. Journal of foreign legislation and comparative law. 2012. № 6. C. 38-49. URL: http://www.nbpublish.com/library_get_pdf.php?id=22795.

28. Judgment of 23 November 1989, Torfaen Borough Council v B \& Q plc., Case C-145/88, ECLI:EU:C:1989:593.

29. Judgment of 15 July 1964, Flaminio Costa v E.N.E.L., Case 6-64, ECLI:EU:C:1964:66. 
30. Judgment of 5 March 1996, Brasserie du Pêcheur SA v Bundesrepublik Deutschland and The Queen v Secretary of State for Transport, ex parte: Factortame Ltd and others, Joined cases C-46/93 and C-48/93, ECLI:EU:C:1996:79.

31. Judgment of 5 October 1994, Commission of the European Communities v. French Republic, Case C-381/93, ECLI:EU:C:1994:370.

32. Judgment of 19 November 1991, Andrea Francovich and Danila Bonifaci and others $\mathrm{v}$ Italian Republic, Joined cases C-6/90 and C-9/90, ECLI:EU:C:1991:428.

33. Judgment of 12 November 1969, Erich Stauder v City of Ulm, Case 29-69, ECLI:EU:C:1969:57.

34. Judgment of 17 December 1970, Internationale Handelsgesellschaft mbH v Einfuhr- und Vorratsstelle für Getreide und Futtermittel, Case 11-70, ECLI:EU:C:1970:114.

35. Judgment of 14 May 1974, J. Nold, Kohlen- und Baustoffgroßhandlung v Commission of the European Communities, Case 4-73, ECLI:EU:C:1974:51.

36. Judgment of 15 June 1978, Gabrielle Defrenne v Société anonyme belge de navigation aérienne Sabena, Case 149/77, ECLI:EU:C:1978:130.

37. Judgment of 8 April 1976, Gabrielle Defrenne v Société anonyme belge de navigation aérienne Sabena, Case 43-75, ECLI:EU:C:1976:56.

38. Judgment of 26 June 2001, Susanna Brunnhofer v Bank der österreichischen Postsparkasse AG, Case C-381/99, ECLI:EU:C:2001:358.

39. Judgment of 17 September 2002, A.G. Lawrence and Others v Regent Office Care Ltd, Commercial Catering Group and Mitie Secure Services Ltd., Case C-320/00, ECLI:EU:C:2002:498.

40. Judgment of 14 April 1994, A. v Commission of the European Communities, Case T-10/93, ECLI:EU:T:1994:39.

41. Judgment of 27 October 1976, Vivien Prais v Council of the European Communities, Case 130-75, ECLI:EU:C:1976:142.

42. Judgment of 10 July 2008, Centrum voor gelijkheid van kansen en voor racismebestrijding v Firma Feryn NV, Case C-54/07, ECLI:EU:C:2008:397.

43. Judgment of 18 December 2014, Fag og Arbejde (FOA) v Kommunernes Landsforening (KL), Case C-354/13, ECLI:EU:C:2014:2463.

44. Judgment of 17 February 1998, Lisa Jacqueline Grant v South-West Trains Ltd., Case C-249/96, ECLI:EU:C:1998:63.

45. Judgment of 14 March 2017, Samira Achbita and Centrum voor gelijkheid van kansen en voor racismebestrijding v G4S Secure Solutions NV, Case C-157/15, ECLI:EU:C:2017:203.

46. Judgment of 4 April 1974, Commission of the European Communities v French Republic, Case 167-73. URL: http://curia.europa.eu/juris/showPdf.jsf 
?text $=\&$ docid $=88640 \&$ pageIndex $=0 \&$ doclang $=E N \&$ mode $=1$ st $\&$ dir $=\&$ occ $=$ first \&part $=1 \&$ cid $=7444244$.

47. Judgment of 18 January 1990, Henri Maurissen and European Public Service Union v Court of Auditors of the European Communities, Joined cases C-193/87 and C-194/87, ECLI:EU:C:1990:18.

48. Judgment of 18 December 2007, Laval un Partneri Ltd v Svenska Byggnadsarbetareförbundet, Case C-341/05, OJ C 281, 12.11.2005.

49. Judgment of 11 December 2007, International Transport Workers' Federation and Finnish Seamen's Union v Viking Line ABP and OÜ Viking Line Eesti, Case C-438/05, ECLI:EU:C:2007:772.

50. Judgment of 15 July 2010, European Commission v Federal Republic of Germany, Case C-271/08, ECLI:EU:C:2010:426.

51. Judgment of 8 June 1994, Commission of the European Communities v United Kingdom of Great Britain and Northern Ireland, Case C-382/92, ECLI:EU:C:1994:233.

52. Judgment of 21 September 1999, Albany International BV v Stichting Bedrijfspensioenfonds Textielindustrie, Case C-67/96, ECLI:EU:C:1999:430.

53. Hanlon J. European Community Law. London. 2003. 408 p.

54. Кернз В. Вступ до права Європейського Союзу / пер. $з$ англ. Київ : Знання, 2003. $381 \mathrm{c.}$

55. Колесніченко В.В. Принципи права Свропейського Союзу: загальнотеоретичне дослідження : автореф. дис. на здобуття наук. ступеня канд. юрид. наук : спец. 12.00.01. «Теорія та історія держави і права; історія політичних і правових учень». Одеса, 2010. 22 с.

56. Колесніченко В.В. Принципи права Свропейського Союзу у світлі Лісабонського договору. Актуальні проблеми політики : зб. наук. пр. / редкол.: С.В. Ківалов (керівник авт. кол.), Л.І. Кормич (ред.), М.А. Польовий (відп. секр.) та ін. ; ОНЮА, Південноукр. центр гендер. проблем. Одеса, 2009. Вип. 36. С. 181-187.

57. Колодій А.М. Принципи права: генеза, поняття, класифікація та реалізація. Альманах права. 2012. Вип. 3. С. 42-46.

58. Комарова Т.В. Юрисдикція Суду Європейського Союзу. Харків : Право, 2010. 360 с.

59. Консолідовані версії Договору про Свропейський Союз та Договору про функціонування Європейського Союзу з протоколами та деклараціями URL: http://zakon3.rada.gov.ua/laws/show/994_b06.

60. Лазовскі А. Верховенство права Свропейського Союзу: юридична авантюра, що окупилась. Право Украӥни. 2019. № 6. С. 35-52. 
61. Лесько T.B. Захист прав людини в Європейському Союзі. URL: https://conferences.vntu.edu.ua/index.php/all-hum/all-hum-2018/paper/ download/4269/3536.

62. Lenaerts K., J.A. Gutierrez-Fons. The constitutional allocation of powers and general principles of EU Law. Common Market Law Review 47. 2010, Pp. 1629-1669.

63. Marcelo Kohen \& Berenice Schramm. General Principles of Law, Oxford Bibliographies Online, Ed. Tony Carty. New York : Oxford University Press, 2013. 23 p.

64. Митник О. Європейська інтеграція та права людини в Україні: нові виклики та перспективи. Сучасні виклики українського права в контексті європейської інтеграиії : тези доповідей учасників постійно діючого наукового семінару 29 квітня 2016 р. / за заг. ред. проф. Р.С. Мельника. Бюлетень № 1 (1) квітень 2016 p. C. 9. URL: http://zdr.knu.ua/ images/libraryfiles/2.pdf.

65. Назаренко О.А. Загальні принципи права $\mathrm{CC} \mathrm{в} \mathrm{правовій} \mathrm{системі} \mathrm{ЄС.}$ Правове регулювання економіки. 2015. № 15. С. 242-249. URL: http://irbis-nbuv.gov.ua/cgi-bin/irbis_nbuv/cgiirbis_64.exe?C21COM=2\&I21 DBN=UJRN\&P21DBN=UJRN\&IMAGE_FILE_DOWNLOAD=1\&Image_ file_name=PDF/pre_2015_15_23.pdf.

66. Опришко В.Ф. Право Європейського Союзу. Загальна частина: підручник / В.Ф. Опришко, А.В. Омельченко, А.С. Фастовець. Київ : KHEУ, 2002. $458 \mathrm{c}$.

67. Plender R. Equality and Non-Discrimination in the Law of European Union. 7 Pace Int'l L. Rev., 57(1995), Pp. 57-80. URL: http:// digitalcommons.pace.edu/pilr/vol7/iss1/2.

68. Погребняк С.П. Основоположні принципи права (змістовна характеристика). Харків : Право, 2008. 240 с.

69. Постовалова Т.А. Трудовое право Европейского Союза: теория и практика. «Издательство «Проспект», 2015. 544 с.

70. Пилипенко П.Д. Про засади інтеграції трудового права України до трудового права Європейського Союзу. Актуальні проблеми сочіального права. Випуск 9. Матеріали міжнародної науково-практичної конференції «Украйнська правнича наука та ї̈ вплив на сучасні реформи» (до 95-річчя Цигилика Теодора Івановича) 6 грудня 2019 року. Львів, «ГАЛИЧ-ПРЕС», 2020. $312 \mathrm{c}$.

71. Право Європейського Союзу : навчальний посібник / За ред. Р.А. Петрова. 5-те видання, змінене і доповнене. Київ : Істина, 2013. 384 с. 
72. ПРАВО Европейского Союза. НОВЫЙ ЭТАП ЭВОЛЮЦИИ: 2009-2017 годы. Москва: Изд-во «Аксиом», 2009. 304 с. URL: http://www.eurocollege.ru/fileserver/books/esi-library5.pdf.

73. Проєкт Трудового кодексу України. Книга перша. Від 24.07.2017. URL: http://search.ligazakon.ua/__doc2.nsf/link1/DH1A200V.html.

74. Радзівілл О.А. Загальноправові принципи як джерела міжнародного економічного права. Юридична наука. 2014. № 2. С. 54-55. URL: http://nbuv.gov.ua/UJRN/jnn_2014_2_7.

75. Regulation (EU) No 492/2011 of the European Parliament and of the Council of 5 April 2011 on freedom of movement for workers within the Union Text with EEA relevance. URL: https://eur-lex.europa.eu/legalcontent/en/TXT/?uri=CELEX:32011R0492.

76. Stein Evju.'Revisiting the Posted Workers Directive: Conflict of Laws and Laws in Contrast", in C. Barnard and O. Odudu (eds.) The Cambridge Yearbook of European Legal Studies, Vol. 12, 2009-2010, P. 151-182. URL: https://www.researchgate.net/publication/305942091_Revisiting_the_Posted_W orkers_Directive_Conflict_of_Laws_and_Laws_in_Contrast.

77. Стрєльцова О.В. Загальні принципи права як джерело права Європейського Союзу. Альманах права. 2012. Вип. 3. Рp. 265-269.

78. Susanne K. Schmidt, Michael Blauberger \& Dorte Sindbjerg Martinsen. Free movement and equal treatment in an unequal union, Journal of European Public Policy, 2018. 25:10, pp. 1391-1402. DOI: 10.1080/13501763.2018. 1488887.

79. Татам А. Право Європейського Союзу / пер. $з$ англ. Київ : Абрис, 1998. $424 \mathrm{c}$.

80. Толкачова Н.Б. Принцип захисту основних прав людини у практиці Суду Європейських Співтовариств. Держава i право. 2009. Вип. 46. C. 532-537. URL: http://dspace.nbuv.gov.ua/bitstream/handle/123456789/9075/ 93-Tolkachova.pdf?sequence $=1$.

81. Трудове право України: Академічний курс : підручник для студентів вищих навчальних закладів / П.Д. Пилипенко, В.Я. Бурак, 3.Я. Козак та ін. ; За ред. П.Д. Пилипенка. 5-тє вид., перероб. і доп. Київ : Видавничий Дім «Ін Юре», 2014. 552 с.

82. Хартия ЕС об основных правах / под ред. д. ю. н., проф. С.Ю. Кашкина. Москва : Юриспруденция, 2001. 208 с.

83. Xenidis Raphäle. European Regulatory Private Law: The Transformation of European Private Law from Autonomy to Functionalism in Competition and Regulation (ERPL). EUI Working Paper. LAW 2017/04. 44 p.

84. Фулей Т. Загальнолюдські (загальноцивілізаційні) принципи права: деякі теоретичні аспекти. Право України. 2003. № 7. С. 24-29. 
85. Шеплякова Т.В. Колективні трудові права працівників за законодавством СС. Часопис Киїського університету права. 2013. № 4. C. 376-379. URL: http://nbuv.gov.ua/UJRN/Chkup_2013_4_92.

86. Юхимюк О. Еволюція системи загальних принципів права Європейського Союзу. Історико-правовий часопис. 2016. № 1. С. 53-57. URL: http://nbuv.gov.ua/UJRN/ipch_2016_1_12.

\section{Information about authors:}

Rym O. M.,

Candidate of Juridical Sciences, Associate Professor at the Department of Social Law Ivan Franko National University of Lviv 1, Universytetska str., Lviv, 79000, Ukraine

Pylypenko P. D., Doctor of Juridical Sciences, Professor, Head of the Department of Social Law Ivan Franko National University of Lviv 1, Universytetska str., Lviv, 79000, Ukraine 